\title{
IMPORTANCE-PERFORMANCE ANALYSIS BASED BALANCED SCORECARD FOR PERFORMANCE EVALUATION IN HIGHER EDUCATION INSTITUTIONS: AN INTEGRATED FUZZY APPROACH
}

\author{
Salman NAZARI-SHIRKOUHI ${ }^{1}{ }^{*}$, Saeed MOUSAKHANI ${ }^{2}$, \\ Mahdokht TAVAKOLI ${ }^{2}$, Mohammad Reza DALVAND ${ }^{3}$, \\ Jonas ŠAPARAUSKAS ${ }^{4}$, Jurgita ANTUCHEVIČIENE ${ }^{4}$ \\ ${ }^{1}$ School of Industrial Engineering, Fouman Faculty of Engineering, \\ College of Engineering, University of Tehran, Tehran, Iran \\ ${ }^{2}$ School of Industrial Engineering, College of Engineering, University of Tehran, Tehran, Iran \\ ${ }^{3}$ Department of Management, Kazerun Branch, Islamic Azad University, Kazerun, Iran \\ ${ }^{4}$ Department of Construction Management and Real Estate, \\ Vilnius Gediminas Technical University, Sauletekio al. 11, LT-10223 Vilnius, Lithuania
}

Received 27 March 2019; accepted 10 December 2019

\begin{abstract}
Recognizing the state of the universities and disrupting their functions by performance evaluation helps them adopt more appropriate educational, research and institutional policies to conduct a university system. In this paper, the importance of the services provided and the activities of the university are determined by means of the balanced scorecard (BSC) approach, and the performance assessment structure is implemented based on an integrated fuzzy multi-criteria decision making (MCDM) approach. For this purpose, interdependencies between BSC aspects and effective indicators weight are determined by Fuzzy Decision-Making Trial and Evaluation Laboratory (FDEMATEL) and Fuzzy Analytic Network Process (FANP) methods, respectively. Accordingly, the final weight of the effective indexes on the performance evaluation of university is presented and the educational income is recognized as one of the most important indicators. Finally, the priorities of universities are specified in order to improve the performance and policy making by the importance-performance analysis (IPA). Therefore, the growth of the number of students should be considered as one of the most important stages in improving university performance in the future in order to achieve educational income. Moreover, the guidelines for universities and higher education institutions are presented to identify key factors in implementing and improving performance.
\end{abstract}

Keywords: performance evaluation, importance-performance analysis, balanced scorecard, universities and higher education institutions, fuzzy DEMATEL, fuzzy ANP.

JEL Classification: A10, A20, A29, C02, D81, I23.

*Corresponding author. E-mail: snnazari@ut.ac.ir

Copyright (C) 2020 The Author(s). Published by VGTU Press

This is an Open Access article distributed under the terms of the Creative Commons Attribution License (http://creativecommons. org/licenses/by/4.0/), which permits unrestricted use, distribution, and reproduction in any medium, provided the original author and source are credited. 


\section{Introduction}

Nowadays, the study of performance in different sectors of the country's economy is one of the important issues that have attracted the attention of many organizations. The application of a performance evaluation system by organizations is one of the key and vital tasks of organizations to survive in a competitive world (Borujeni \& Gitinavard, 2017; Rezaie et al., 2013; Sun, 2010). On the other hand, non-profit universities, as one of the sectors of the country's economy have an important and special role to achieve industrial and economic development (Dyson, 2000; Iranmanesh et al., 2019). It is necessary to know the status of universities for continuing the targeted activities of the universities in the field of research and technology. The performance evaluation system is a valuable help in achieving this goal. Therefore, strengths and weaknesses of universities can be recognized by performance evaluation systems (Hassan et al., 2016).

The balanced scorecard (BSC) approach is one of the tools to evaluate the performance of organizations (Alipour et al., 2019; Beheshtinia \& Omidi, 2017; Dizaji et al., 2018). The performance evaluation system, based on BSC, provides a basis for the proper, optimal and successful implementation of the organization's strategy and creates a framework for individuals to find new perspectives for their activities and organization. The BSC has been widely applied in manufacturing, service, non-government and government organizations, and significant effects have been reported by organizations in many cases (Dinçer et al., 2017). Also, this approach is capable of considering the long-term mission of the organization in developing strategies and evaluating performance (Papenhausen \& Einstein, 2006).

So far, several tools and methods have been proposed for solving performance evaluation problems using multi-criteria decision making (MCDM) methods (Hassan et al., 2016). For example, Analytical Hierarchy Process (AHP) model (Sohrabvandi et al., 2017), ANP method (Saaty, 1996), DEMATEL method (Gabus \& Fontela, 1972; Solgi et al., 2019), and etc. are developed regarding the precise information. Furthermore, in some studies the aforementioned techniques are extended to address the vagueness and uncertain situation (Gitinavard \& Akbarpour Shirazi, 2018; Gitinavard \& Zarandi, 2016).

Due to the issues raised in relation to necessity of studying the performance evaluation based on indicators and BSC aspects, the adoption of the appropriate method is very important for implementing this framework. In this study, performance indicators are applied based on a BSC aspects and a comprehensive list of them is provided as one of the main steps in performance evaluation. The purpose of this study is to develop a BSC structure in line with the strategic objectives of the organization. In this regard, a hybrid MCDM model is utilized based on DEMATEL and ANP models under uncertainty for evaluating the performance of a non-profit university in Iran.

The rest of paper is organized as follows: Section 1 provides a comprehensive literature survey of the performance evaluation of universities. In section 2, the proposed evaluation model based on DEMATEL and ANP is prepared. In addition to, a real case study about the performance evaluation of universities is intended to indicate the efficiency and applicability of the proposed approach in section 3. In section 4, comparison analysis is elaborated based on importance-performance matrix. Finally, some concluding remarks and future directions are presented. 


\section{Literature review}

In this section, after briefly describing the history and methods of the performance evaluation, the comprehensive literature review related to the performance evaluation of universities is presented in two parts of the methods and criteria.

The performance evaluation of an organization is very important for each manager and can effective on their decision. It is a comparison of the actual performance levels with the targets of the predetermined performance levels (Slizyte \& Bakanauskiene, 2007). Research literature review has broadly focused on the role of performance evaluation such as supporting the management process (Nuut et al., 2002), explaining the effectiveness and accountability of the organization (Baker, 2002), ensuring and tracking the quality of the organization (Baba \& Shukor, 2003) and comparing different data sources and strategies planning (Nuut, 2006).

In addition, performance evaluation is influential on decisions, policies and strategies of organizations and managers. Therefore, proper implementation of performance evaluation in an organization leads to creating responsibility in the organization's staff. Performance assessment in an organization can be considered as a basis for the establishment of a system of punishment and encouragement, which in this way also provides the ability to create a competitive environment in the organization (Atafar et al., 2013). The role of performance evaluation in developing performance improvement appears when the organizations need to continuously improve the different components (Ha \& Yang, 2018).

The attention of the organization (university) to customer orientation (student-centric) has had a great influence on the performance evaluation of universities in different parts of the world. Universities need to choose an appropriate method for evaluating performance and accurately estimating their performance in order to improve the level of accountability and customer orientation (Al-Hosaini \& Sofian, 2015). Many researchers have addressed the performance evaluation in universities (Hassan et al., 2016). Kai (2009) expresses that the accountability in a higher education institution requires the organization to achieve the intended goals and expected performance. Also, he introduced performance evaluation of the universities as a basic approach to achieving accountability and an important tool for quality assurance. Sarrico et al. (2010) presented a comprehensive literature review of performance assessment and qualitative methods in higher education institutions and proposed various points in the implementation of these methods. Yao et al. (2014) regarded the multiple linear regression methods, based on non-financial data, in order to evaluate performance in China. Nazarko and Šaparauskas (2014) applied DEA method for efficiency evaluation of Polish universities of technology. Ding and Zeng (2015) implemented the TOPSIS and information entropy weight (IEW) methods to assess the 68 universities in China. Dai and Li (2016) applied AHP to specify the index weight and utilized fuzzy comprehensive assessment method to rank the private higher education.

A review of the literature shows that a BSC is widely used to design a performance evaluation system. The performance evaluation system based on BSC provides a basis for the proper, optimal and successful implementation of the organization's strategy and creates a framework for individuals to find new perspectives for their activities and organization. On 
the other hand, the BSC is a technique that is used extensively to measure the performance of organizations, based on four main areas: financial, customer, internal processes, and learning and growth. Kaplan and Norton (1995) pointed explicitly to the existence of causal relationships between the four dimensions of BSC approach. Also, they concluded that there was a causal relationship between the goals and the criteria of these four dimensions in the process of balancing scorecard analysis.

Accordingly, it can be concluded that to achieve financial results (Financial perspective), the organization must create value for its customers (Customer perspective). This won't happen unless it is distinct in its operational processes and conforms them to the needs of their customers (Internal processes perspective) and it is not possible unless the organization has created a suitable work environment for its employees (Learning and growth perspective).

Many researchers have benefited from integrated BSC and MCDM for performance evaluation and the cause and effect relationships among the four BSCs approach (Ling Sim \& Chye Koh, 2001; S.-I. Wu \& Hung, 2007). Accordingly, learning capability and financial performance have a directly positive correlation with each other (Tippins \& Sohi, 2003). In summary, the growth and learning aspect has a positive effect on the financial perspective. Lin and Wu (2008) applied DEMATEL technique for creating and analyzing a structural model including cause and effect relationships between BSC dimensions.

Although the concept of BSC has been widely accepted and applied in the business industry, apparently it has not been used extensively in the educational sector. Following the successful implementation of a BSC in profit organizations, many non-profit organizations sought to implement this framework. Today, many higher education institutions apply BSC approach. Papenhausen and Einstein (2006) presented a comprehensive guideline for implementing a BSC approach in the faculty of business, based on specific goals and appropriate measures for each one in their faculty. Chen et al. (2006) applied a BSC approach to performance evaluation as a strategic tool in Taiwan's higher education. The results of their research indicate that a BSC can be successfully implemented in higher education if supported by senior executives, and the indicators of performance measurement are designed to achieve the goals correctly. Table 1 shows the evolution of previous research in the application of BSC in higher education institutions.

Today, the attention of many researchers has been attracted to the field of performance evaluation of universities and higher education institutions because of the critical role of these institutions in the society and the existence of a competitive market among universities. Traditional methods of performance evaluation based on financial criteria are unable to meet the increasing needs of universities. In addition, traditional performance evaluation systems have limitations such as lack of full reflection of reasons for success or failure of the organization and failure to properly establish cause-effect relationships among the factors driving success and achievement. Therefore, these systems cannot support organization management plans. By studying the subject literature, performance evaluation based on BSC approach is able to evaluate the organization's performance from a variety of financial and non-financial perspectives. Also, this approach attempts to establish a link between operational controls and short-term activities and long-term vision and business strategies. 
Table 1. Use of BSC in higher education institutions

\begin{tabular}{|l|l|l|}
\hline \multicolumn{1}{|c|}{ Author (s) } & \multicolumn{1}{|c|}{ Research topic } & \multicolumn{1}{|c|}{ Methodology } \\
\hline $\begin{array}{l}\text { Zolfani and } \\
\text { Ghadikolaei } \\
(2013)\end{array}$ & $\begin{array}{l}\text { Implemented the BSC approach to evaluate the performance } \\
\text { of university based on MCDM methods. }\end{array}$ & $\begin{array}{l}\text { DEMATEL, ANP } \\
\text { and VIKOR }\end{array}$ \\
\hline Atafar et al. (2013) & $\begin{array}{l}\text { Applied the BSC approach in the performance assessment } \\
\text { an educational unit in Iran. }\end{array}$ & ANP \\
\hline $\begin{array}{l}\text { Ramasamy et al. } \\
(2016)\end{array}$ & $\begin{array}{l}\text { Suggested a hybrid framework to evaluate the performance } \\
\text { of institutions in higher education. }\end{array}$ & AHP \\
\hline $\begin{array}{l}\text { Gamal and } \\
\text { Soemantri (2017) }\end{array}$ & $\begin{array}{l}\text { Determined the BSC effect on performance of future private } \\
\text { colleges. }\end{array}$ & linear regression \\
\hline $\begin{array}{l}\text { Özdemir and } \\
\text { Tüysüz (2017) }\end{array}$ & $\begin{array}{l}\text { Evaluated Turkish higher education based on the BSC } \\
\text { approach. }\end{array}$ & $\begin{array}{l}\text { FDEMATEL and } \\
\text { FANP }\end{array}$ \\
\hline Alani et al. (2018) & $\begin{array}{l}\text { Utilized the BSC approach to evaluate performance and } \\
\text { measure quality services in higher education in Oman. }\end{array}$ & $\begin{array}{l}\text { null hypothesis, } \\
\chi^{2} \text {, and } \\
\text { regression } \\
\text { analysis }\end{array}$ \\
\hline $\begin{array}{l}\text { Nurcahyo et al. } \\
\text { (2018) }\end{array}$ & $\begin{array}{l}\text { Formulated strategic based on BSC approach in Higher } \\
\text { Education Institution. }\end{array}$ & $\begin{array}{l}\text { Borda (ranking) } \\
\text { and AHP }\end{array}$ \\
\hline
\end{tabular}

The main contribution of this paper is to apply the integrated ANP- DEMATE -IPA technique in the fuzzy environment based on BSC approach. Applying these approaches provides a framework for the organization to implement its strategy and its results. In this regard, the approach presented in this paper has the advantage over other approaches that can identify the main dimensions of the organization in the context of causal relationships. As a result, decisions and related executive actions can be transformed into a very specific way of relationship for strategy transfer across the organization.

Therefore, the purpose of this study is to investigate the effect of each of the sub-components of four dimensions of BSC and provide a comprehensive performance evaluation framework for performance assessment of the non-profit universities. The proposed method will be able to consider multiple criteria simultaneously, taking into consideration the relationships between each of factors and sub-factors. In this research, the DEMATEL and ANP techniques in fuzzy environment are applied to describe the relationship between different criteria and indicators of performance evaluation.

\section{The proposed approach framework}

As mentioned before, the BSC approach is applied to evaluate the performance of a university, and to achieve this goal the integrated approach is proposed based on ANP and DEMATEL techniques in fuzzy environments. The inputs of this model have included a set of performance evaluation indicators, derived from BSC metrics. In general, the proposed research framework, including how to process a fuzzy system, is shown in Figure 1. 


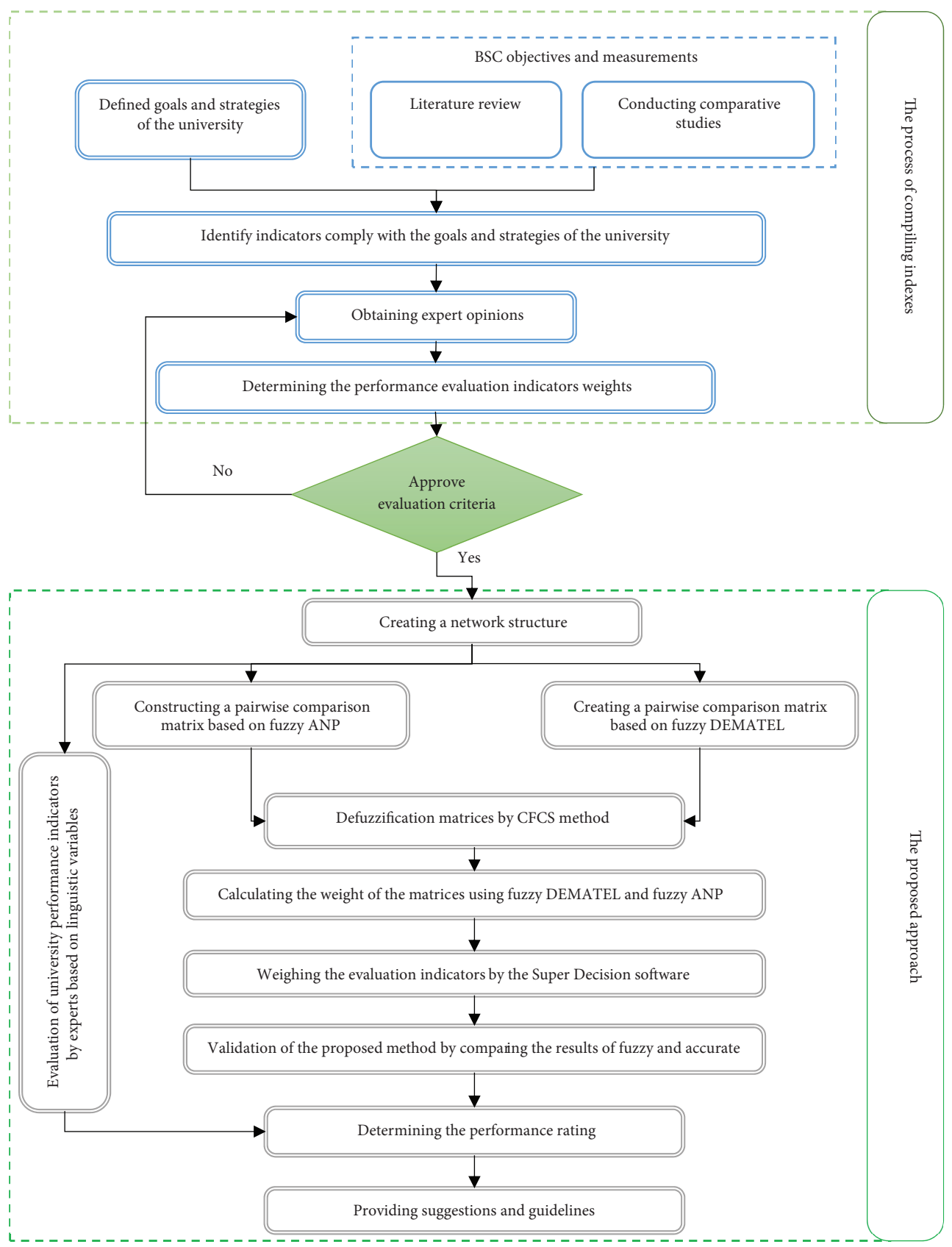

Figure 1 . The proposed framework for evaluating university performance 


\subsection{DEMATEL methodology}

The DEMATEL method was introduced between 1972 and 1976 by the Battle Memorial Institute in Genoa (Gabus \& Fontela, 1972). The causal relationships between indicators were converted into a tangible structural model in the decision-making issues (Tzeng et al., 2007). The DEMATEL technique operates based on directional graphs, and these graphs are able to display the directional relationships between the subsystems. In order to easily use DEMATEL method, this study summarizes the weighting method, used by Gabos and Fogtella (1972) and presents the following in four main steps:

Step 1: Establish a direct relation matrix.

Step 2: The direct relation matrix $Z$ is converted into a normalized matrix of direct relations using Eq. (1) (Hung et al., 2006):

$$
\begin{gathered}
X=s \cdot Z ; \\
s=\min \left\{1 / \max _{1 \leq i \leq n} \sum_{j=1}^{n} z_{i j}, 1 / \max _{1 \leq j \leq n} \sum_{i=1}^{n} z_{i j}\right\}, i, j=1,2, \ldots, n .
\end{gathered}
$$

Step 3: Construct the overall relationship matrix.

The overall relations matrix $(T)$ is calculated using the Eq. (3):

$$
T=X(I-X)^{-1}
$$

where $I$ is the elementary matrix.

Step 4: Provide the causal chart.

The sum of the elements of the rows and columns of the matrix $T$ is calculated by the Eqs (4) to (6), and they are named as the $D$ and $R$ vectors, respectively. Then, the horizontal axis value of the diagram (importance of axis) is calculated by summing $R$ and $D$ vectors indicating the importance of the relevant criterion. Similarly, the vertical axis of the diagram (dependency axis) is calculated by the relationship $(D-R)$. The criteria are divided into two groups of cause and effect through these two axes.

$$
\begin{gathered}
T=\left[t_{i j}\right]_{n \times n}, \quad i, j=1,2, \ldots, n ; \\
D=\left[\sum_{j=1}^{n} t_{i j}\right]_{n \times 1}=\left[t_{i .}\right]_{n \times 1} ; \\
R=\left[\sum_{i=1}^{n} t_{i j}\right]_{1 \times n}=\left[t_{. j}\right]_{n \times 1} .
\end{gathered}
$$

\subsection{Group fuzzy DEMATEL}

So far, we have mentioned the DEMATEL technique and its application in certain conditions. However in many cases in real life, we face with decision data that come from human judgments which are always confused. In such a situation, traditional methods that use certain values appear to be inappropriate. Therefore, in this research, the fuzzy format of the DEMATEL method is used, due to the more accurate results and simpler decision making. 
The procedures for performing the fuzzy DEMATEL are described below (Lin \& Wu, 2008).

Step 1: Establish a fuzzy direct relation matrix.

The pairwise comparisons are established in order to investigate the internal relationships among evaluation indices and to determine the effect of factor $i$ on factor $j$. The linguistic variable based on triangular fuzzy numbers is presented in Table 2.

Table 2. The linguistic variables and corresponding fuzzy numbers (W.-W. Wu \& Lee, 2007)

\begin{tabular}{|l|c|}
\hline \multicolumn{1}{|c|}{ Values of linguistic scales } & Triangular fuzzy numbers \\
\hline (VH) influence Very high & $(0.75,1.0,1.0)$ \\
\hline (H) High influence & $(0.5,0.75,1)$ \\
\hline (L) Low influence & $(0.25,0.5,0.75)$ \\
\hline (VL) Very low influence & $(0,0.25,0.5)$ \\
\hline (NO) No influence & $(0,0,0.25)$ \\
\hline
\end{tabular}

Step 2: Formation of a normalized matrix (Matrix $X$ ).

In this step, the CFCS method (Opricovic \& Tzeng, 2003) is used for the formation of a normalized matrix of direct relations based on following equations:

$$
\begin{aligned}
x l_{i j}^{k} & =\left(l_{i j}^{k}-\min l_{i j}^{k}\right) / \Delta_{\min }^{\max } ; \\
x m_{i j}^{k} & =\left(m_{i j}^{k}-\min l_{i j}^{k}\right) / \Delta_{\min }^{\max } ; \\
x r_{i j}^{k} & =\left(r_{i j}^{k}-\min l_{i j}^{k}\right) / \Delta_{\min }^{\max } .
\end{aligned}
$$

In this equation: $\Delta_{\min }^{\max }=\max r_{i j}^{k}-\min l_{i j}^{k}$.

Step 3: Calculate the left normal (ls) and right normal (rs).

$$
\begin{aligned}
& x l s_{i j}^{k}=x m_{i j}^{k} /\left(1+x m_{i j}^{k}-x l_{i j}^{k}\right) ; \\
& x r s_{i j}^{k}=x r_{i j}^{k} /\left(1+x r_{i j}^{k}-x m_{i j}^{k}\right) .
\end{aligned}
$$

Step 4: Determine the value of the final normal certain.

$$
x_{i j}^{k}=\left[x l s_{i j}^{k}\left(1-x l s_{i j}^{k}\right)+x r s_{i j}^{k}\right] /\left[1-x l s_{i j}^{k}+x r s_{i j}^{k}\right] .
$$

Step 5: Calculate the certain values.

$$
z_{i j}^{k}=\min l_{i j}^{k}+x_{i j}^{k} \Delta_{\min }^{\max } .
$$

Step 6: Combine the certain values.

$$
z_{i j}=\frac{1}{p}\left(z_{i j}^{1}+z_{i j}^{2}+\ldots+z_{i j}^{P}\right) .
$$

Step 7: Construct the overall relations matrix.

The overall relations matrix $T$ is calculated using the Eq. (3). 
Step 8: Generate the causal chart.

The value of the horizontal axis of the diagram (importance or effect axis) is calculated through the sum of $R$ and $D$ vectors $(D+R)$. The vertical axis of the diagram (dependence or impact axis) is calculated by the relationship $(D-R)$.

$\left\{\begin{array}{l}\text { The relevant criterion belongs to the cause group; if } D-R \succ 0 ; \\ \text { The relevant criterion belongs to the effect group; if } D-R \prec 0 .\end{array}\right.$

Therefore, the causal diagram is obtained by drawing points with coordinates of $(D+R$, $D-R)$.

Also, the normalized $T$-matrix can be used as an estimate of internal weight among the criteria considered in the fuzzy ANP model. In this study, the normalized $T$ matrix is used to find the internal relationships between the main BSC criteria and the internal weight of the communication between them.

\subsection{Fuzzy ANP model}

The pairwise comparisons' questionnaire have been used based on the tangible expressions in the collection phase of the experts' opinion. The scale used for this study is a 1-9 scale proposed by Tesfamariam and Sadiq (2006), based on Saaty's scale (Table 3).

Table 3. Converts linguistic variables to triangular fuzzy numbers

\begin{tabular}{|l|c|}
\hline \multicolumn{1}{|c|}{ Linguistic variable } & Triangular fuzzy number \\
\hline Equal importance & $(1,1,1)$ \\
\hline Weak importance & $(2,3,4)$ \\
\hline Essential or strong importance & $(4,5,6)$ \\
\hline Demonstrated importance & $(6,7,8)$ \\
\hline Extreme importance & $(8,9,9)$ \\
\hline $\begin{array}{l}\text { Intermediate values between two } \\
\text { adjacent judgments }\end{array}$ & $(X-1, X, X+1)$ \\
\hline Mutual triangular numbers & $(1 /(X+1), 1 / X, 1 /(X-1))$ \\
\hline
\end{tabular}

\section{Defuzzification of expert's opinions}

In this research, first, the fuzzy responses are converted to the definitive scale in order to assess the compatibility of responses. Second, the definition of adaptation in the traditional hierarchical analysis method is used to evaluate the accuracy and consistency of responses. Various methods have been suggested for defuzzifying the fuzzy pairwise comparison matrix. In this research, the Opricovic and Tzeng (2003) method and Eqs (11) to (17) are used to defuzzifying the fuzzy expert response. The reason for using this method is to apply of maximum, minimum and membership function of fuzzy set in calculating total score simultaneously.

\section{Calculating the consistency rate}

In this step, the pairwise comparison matrix is created for the criteria $n\left(C_{1}, C_{2}, \ldots, C_{n}\right)$. 


$$
\begin{gathered}
a_{i j}=1 / a j i, \quad i \neq j ; \\
a_{i i}=1, \forall i .
\end{gathered}
$$

Then the decision-making matrix is a reciprocal decision-making matrix which leads to achieve consistency weights. If Eq. (17) is met then the weights will be completely consistent.

$$
a_{i j}=a_{i k} a_{k j} \forall i, j, k
$$

If the decision matrix is reciprocal and its elements are completely transitive, then the weights will be completely consistent and the weights can be obtained through the following equation:

$$
\operatorname{CFCS}(\tilde{A})=\left(\left[w_{i} / w_{j}\right]\right)_{n \times n} .
$$

Also, the following equations can be used to obtain weights when the decision matrix is not completely consistent:

$$
\begin{gathered}
{\left[\operatorname{CFCS}(\tilde{A})-\lambda_{\max }\right] \cdot W=0 ;} \\
\sum w_{i}=1 .
\end{gathered}
$$

$\operatorname{CFCS}(\tilde{A}), \lambda_{\max }, I$ and $W$ represent certain decision matrix, largest specific value of the certain decision matrix, elementary matrix and column matrix of weights, respectively. If the certain decision matrix is completely consistent then it will be $\lambda_{\max }=n$. Where the $A$ value, the consistency indicator, is designed based on this principle. How to calculate this index is as follows:

$$
C I=\left(\lambda_{\max }-n\right) /(n-1) .
$$

This index shows the consistency rate of the certain decision matrix which is dependent on $n$. We divide it into another index, called the Random Index $(R I)$ to deliver this index from $n$. Table 4 shows the values of $R I$ for different values. The new index is obtained as follows:

$$
C R=C I / R I
$$

Table 4. Random index (RI) values for $n$ (Saaty, 1988)

\begin{tabular}{|c|c|c|c|c|c|c|c|c|c|c|c|c|c|c|}
\hline$n$ & 3 & 4 & 5 & 6 & 7 & 8 & 9 & 10 & 11 & 12 & 13 & 14 & 15 \\
\hline$R I$ & 0.58 & 0.90 & 1.12 & 1.24 & 1.32 & 1.41 & 1.45 & 1.49 & 1.51 & 1.48 & 1.56 & 1.57 & 1.59 \\
\hline
\end{tabular}

The upper limit of $C R$ for the consistency of the pairwise comparison matrix is given in Table 5.

Table 5. The upper limit of CR for the consistency of the comparison pair matrix (Liou \& Wang, 1992)

\begin{tabular}{|c|c|c|c|}
\hline$n$ & $3 \times 3$ & $4 \times 4$ & $n \succ 4$ \\
\hline$C R<$ & 0.05 & 0.08 & 0.10 \\
\hline
\end{tabular}




\section{Aggregation of expert's opinion}

In this research, the Eq. (23) is used to obtain an aggregation of the expert's opinion and to obtain the final tables of pairwise comparisons.

$$
\tilde{Z}_{i j}=\left(\sqrt[k]{l_{1} \times l_{2} \times \ldots \times l_{k}}, \sqrt[k]{m_{1} \times m_{2} \times \ldots \times m_{k}}, \sqrt[k]{r_{1} \times r_{2} \times \ldots \times r_{k}}\right) .
$$

\section{A real case study}

The University under study utilizes the experienced and motivated staff and professors to achieve the highest status of the region in educational, research and cultural affairs through the science production and entrepreneurship approach. Nonprofit university as a service sector has an undeniable role in Iran's education and research system so that the successful operation of this university creates the motivation and stimulus in the field of country research, industry and development of its economy. Therefore, non-profit universities like other universities should have a strong and successful performance in achieving these goals and strategies. They can achieve these goals with the help of management and performance evaluation. Hence, in this paper, the importance of the services provided and the activities of the university under study are investigated based on the four aspects of BSC (financial, customer, internal processes, growth and learning). Since it is important to set goals in the studied university and the higher education institution for creating the BSC measures, the relationship between goals and strategic orientations is considered in this paper. In fact, with this action, the strategies and goals of the organization are actually considered in the development of BSC indexes (Table 6).

Table 6. The Relationship between overall strategic direction and university goals

\begin{tabular}{|l|l|}
\hline $\begin{array}{l}\text { Overall strategic } \\
\text { direction }\end{array}$ & \\
\hline $\begin{array}{l}\text { Economic } \\
\text { productivity }\end{array}$ & $\begin{array}{l}\text { - Sustainable economics in a changing environment } \\
\text { - Starting economic activities in authorized and revenue sectors } \\
\text { - Reduce costs }\end{array}$ \\
\hline $\begin{array}{l}\text { Development of } \\
\text { customer service } \\
\text { quality (students) }\end{array}$ & $\begin{array}{l}\text { - Quantitative development of disciplines in graduate and postgraduate degrees } \\
\text { - Growth of students by relying on improving their satisfaction } \\
\text { - Quality assessment of education } \\
\text { - Identifying new interdisciplinary } \\
\text { - Create and approve identified fields } \\
\text { - Develop and equip the library, workshops and laboratories } \\
\text { - Providing classes to the internet and the display system } \\
\text { - Solving welfare needs and providing facilities to students }\end{array}$ \\
\hline $\begin{array}{l}\text { Development } \\
\text { of research and } \\
\text { research culture }\end{array}$ & $\begin{array}{l}\text { - Development and improvement of quantitative and qualitative research } \\
\text { indicators }\end{array}$ \\
\hline $\begin{array}{l}\text { Staff and } \\
\text { learning }\end{array}$ & $\begin{array}{l}\text { - Incrilitating the approval process of research projects } \\
\text { - Delegation of factivity of administrative staff } \\
\text { - Implementation of training courses for professors } \\
\text { - Attending the faculty } \\
\text { - Training of administrative staff } \\
\text { - Fulfilling the welfare needs of administrative staff }\end{array}$ \\
\hline
\end{tabular}


As can be seen, the relationship among the goals and strategic orientations is determined in Table 6. This paper uses a top-down approach to relate university goals to aspects of BSC. This approach begins by examining the final goals and objectives of the university and outlining ways to reach the desired destination. In the next step, each of the university's goals is embedded in the BSC aspects of the university, and by obtaining experts' opinions are identified suitable measures to evaluate the university performance. With this approach, each of the BSC measures is proportional to a specific goal and the relationship among desirable goals with strategies is considered through strategic orientation. It should be noted that experts are involved to create appropriate measures. For this purpose, ten experts (The Executive Committee is composed of the University President and Vice Presidents-With a $\mathrm{PhD}$ and average age of 42 years) are interviewed in relation to the checklist of indicators due to strategies, goals and university general purposes. Finally, the measures (indexes) are determined based on the criteria defined in the articles (On each of the four aspects of BSC, on average, 14 criteria were recognized) and also the most relevancy to the university situation. The BSC measures are expressed in Table 7.

As mentioned in the previous section, the related measures were identified for each of the main the BSC aspects with the help of the results of previous studies, the goals and strategies of the university, as well as the expectations of the stakeholders (experts). The model of the issues under study is understandable through these indicators. In this step, the relationships between the main indexes of the issue (BSC aspects) and relationships between indicators with oneself or other indicators are examined. The internal relations between the four major dimensions of the BSC and the relationships between the indicators have been shown in Figure 2. It is assumed that all indicators of each dimension affect each other.

\subsection{Relationships among BSC aspects}

A Fuzzy DEMATEL technique is used to obtain the relationships among BSC aspects, and the steps this approach were described in the previous section.

In the first step, the impact of BSC aspects on each other is calculated using the scales of Table 6 and with the help of expert opinions. Accordingly, Table 8 shows the relationships among these indicators based on the expert opinions.

Linguistic terms based on Table 2 are converted into numerical values to assess the impact of the BSC aspects on each other, and as result, Table 9 is obtained.

Finally, Table 10 is obtained after applying the CFCS method, based on Eqs (7) to (14) to defuzzifiy the experts' opinions.

Similarly, the certain values are obtained for 9 other experts. The average defuzzification results for these 10 decision makers or the expert consensus matrix are presented in Table 11.

The normalized direct-relations matrix and the overall-relations matrix are obtained from the values of Table 15, with the help of Eqs (1) and (2), and with regards to the maximum amount of sum of rows or columns, which is 1.337 . Tables 12 and 13 show these values.

A remarkable point in this technique is the formation of cause-effect charts that will be a significant contribution to the analysis of the conditions. The cause-effect graph of BSC aspects is shown in Figure 3. In this respect, first, we establish Table 14, by considering the overall-relations matrix. 
Table 7. Assigning university goals to BSC

\begin{tabular}{|c|c|c|c|}
\hline BSC aspects & University goals & Measures & Reference \\
\hline \multirow{4}{*}{ Financial $\left(\mathrm{C}_{1}\right)$} & \multirow{4}{*}{$\begin{array}{l}\text { - Sustainable economics in } \\
\text { a changing environment } \\
\text { - Starting economic } \\
\text { activities in authorized } \\
\text { and revenue sectors } \\
\text { - Reduce costs }\end{array}$} & $\begin{array}{l}\text { Rate of return on } \\
\text { capital }\left(C_{11}\right)\end{array}$ & Alani et al. (2018) \\
\hline & & $\begin{array}{l}\text { Annual income growth } \\
\left(\mathrm{C}_{12}\right)\end{array}$ & Al Kaabi (2018) \\
\hline & & Costs reduction $\left(\mathrm{C}_{13}\right)$ & Al Kaabi (2018) \\
\hline & & $\begin{array}{l}\text { Educational income } \\
\left(\mathrm{C}_{14}\right)\end{array}$ & Vroon (2010) \\
\hline \multirow{6}{*}{ Students $\left(\mathrm{C}_{2}\right)$} & \multirow{6}{*}{$\begin{array}{l}\text { - Quantitative development } \\
\text { of disciplines in graduate } \\
\text { and postgraduate } \\
\text { degrees } \\
\text { - Growth of students by } \\
\text { relying on improving } \\
\text { their satisfaction } \\
\text { - Identifying new } \\
\text { interdisciplinary } \\
\text { - Solving welfare needs and } \\
\text { providing facilities to } \\
\text { students }\end{array}$} & $\begin{array}{l}\text { Students' satisfaction } \\
\left(\mathrm{C}_{21}\right)\end{array}$ & Mourato et al. (2019) \\
\hline & & Service quality $\left(\mathrm{C}_{22}\right)$ & Alani et al. (2018) \\
\hline & & $\begin{array}{l}\text { Developing } \\
\text { relationships with } \\
\text { students }\left(\mathrm{C}_{23}\right)\end{array}$ & Mourato et al. (2019) \\
\hline & & $\begin{array}{l}\text { The growth of the } \\
\text { number of students } \\
\left(\mathrm{C}_{24}\right)\end{array}$ & $\begin{array}{l}\text { Fijałkowska and } \\
\text { Oliveira (2018) }\end{array}$ \\
\hline & & $\begin{array}{l}\text { Graduates' satisfaction } \\
\left(\mathrm{C}_{25}\right)\end{array}$ & $\begin{array}{l}\text { Fijałkowska and } \\
\text { Oliveira (2018) }\end{array}$ \\
\hline & & $\begin{array}{l}\text { Graduate employment } \\
\text { rate }\left(C_{26}\right)\end{array}$ & $\begin{array}{l}\text { Fijałkowska and } \\
\text { Oliveira (2018) }\end{array}$ \\
\hline \multirow{5}{*}{$\begin{array}{l}\text { Internal process } \\
\left(\mathrm{C}_{3}\right)\end{array}$} & \multirow{5}{*}{$\begin{array}{l}\text { - Development and } \\
\text { improvement of } \\
\text { quantitative and } \\
\text { qualitative research } \\
\text { indicators } \\
\text { - Facilitating the approval } \\
\text { process of research } \\
\text { projects }\end{array}$} & $\begin{array}{l}\text { Timeframe for } \\
\text { providing services } \\
\left(\mathrm{C}_{31}\right)\end{array}$ & Al Kaabi (2018) \\
\hline & & $\begin{array}{l}\text { Information technology } \\
\left(\mathrm{C}_{32}\right)\end{array}$ & Mourato et al. (2019) \\
\hline & & $\begin{array}{l}\text { Scientific publications } \\
\left(\mathrm{C}_{33}\right)\end{array}$ & Farid et al. (2008) \\
\hline & & $\begin{array}{l}\text { Productivity of facilities } \\
\left(\mathrm{C}_{34}\right)\end{array}$ & $\begin{array}{l}\text { Chen et al. (2009) } \\
\text { Tseng (2010) }\end{array}$ \\
\hline & & $\begin{array}{l}\text { Standard processes } \\
\left(\mathrm{C}_{35}\right)\end{array}$ & Wu et al. (2011) \\
\hline \multirow{6}{*}{$\begin{array}{l}\text { Learning and } \\
\text { growth }\left(\mathrm{C}_{4}\right)\end{array}$} & \multirow{6}{*}{$\begin{array}{l}\text { - Increased productivity of } \\
\text { administrative staff } \\
\text { - Delegation of faculty to } \\
\text { study trips } \\
\text { - Implementation of } \\
\text { training courses for } \\
\text { professors } \\
\text { - Attending the faculty }\end{array}$} & $\begin{array}{l}\text { Employees and teacher } \\
\text { skills }\left(\mathrm{C}_{41}\right)\end{array}$ & $\begin{array}{l}\text { Fijałkowska and } \\
\text { Oliveira (2018) }\end{array}$ \\
\hline & & \begin{tabular}{|l} 
Satisfaction of \\
employees and \\
professors $\left(\mathrm{C}_{42}\right)$ \\
\end{tabular} & Al Kaabi (2018) \\
\hline & & $\begin{array}{l}\text { Innovation in teaching } \\
\left(\mathrm{C}_{43}\right)\end{array}$ & Mourato et al. (2019) \\
\hline & & $\begin{array}{l}\text { Professors and staffs } \\
\text { encouragement }\left(\mathrm{C}_{44}\right)\end{array}$ & $\begin{array}{l}\text { Fijałkowska and } \\
\text { Oliveira (2018) }\end{array}$ \\
\hline & & $\begin{array}{l}\text { Retaining staff and } \\
\text { teacher }\left(\mathrm{C}_{45}\right)\end{array}$ & Al Kaabi (2018) \\
\hline & & $\begin{array}{l}\text { Courses with new } \\
\text { technologies }\left(\mathrm{C}_{46}\right)\end{array}$ & $\begin{array}{l}\text { Chen et al. (2006) } \\
\text { Karra and } \\
\text { Papadopoulos (2008) }\end{array}$ \\
\hline
\end{tabular}




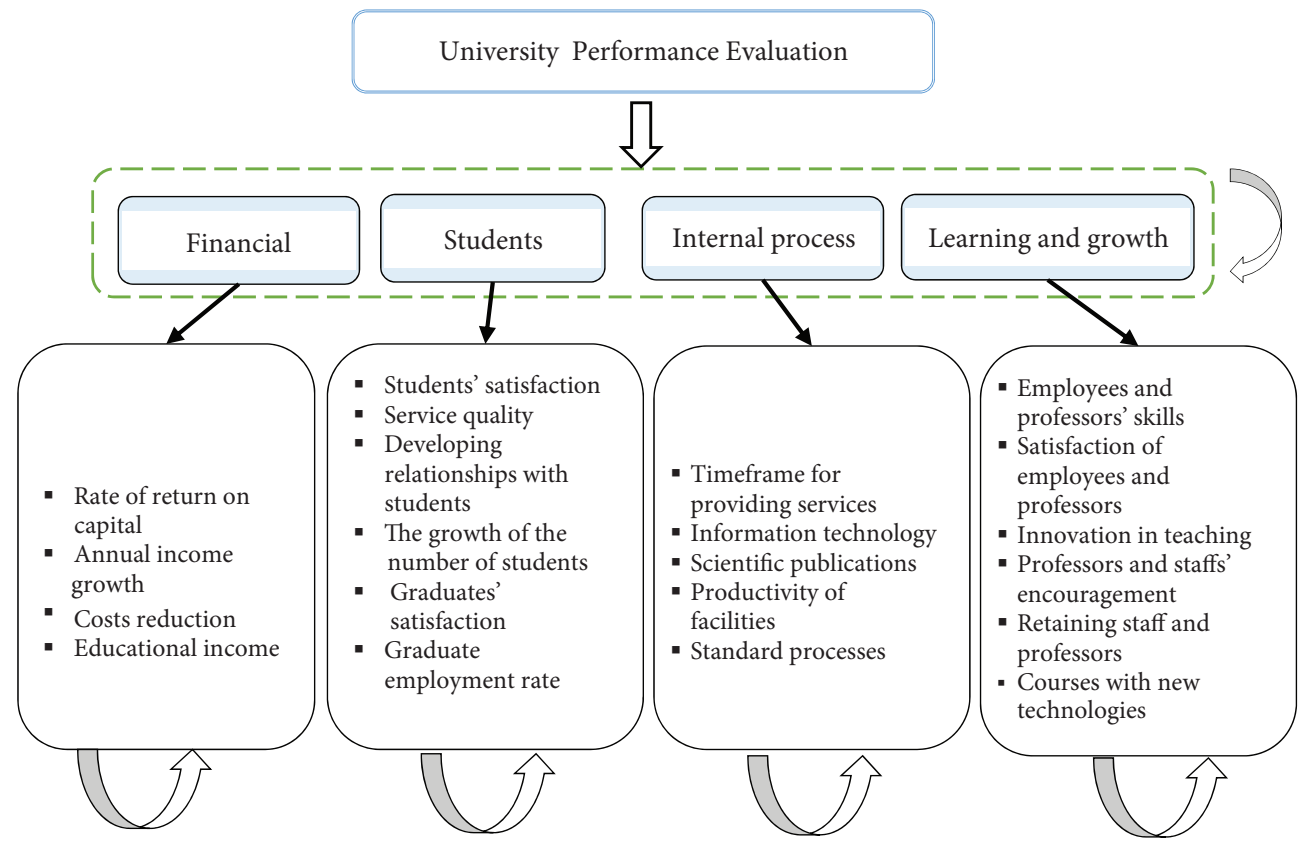

Figure 2. Internal Relationship between BSC Indicators

Table 8. An expert opinion on the impact of BSC aspects

\begin{tabular}{|c|c|c|c|c|}
\hline & $\mathrm{C}_{1}$ & $C_{2}$ & $C_{3}$ & $\mathrm{C}_{4}$ \\
\hline $\mathrm{C}_{1}$ & - & $\mathrm{NO}$ & $\mathrm{VL}$ & $\mathrm{NO}$ \\
\hline $\mathrm{C}_{2}$ & $\mathrm{VH}$ & - & $\mathrm{VH}$ & $\mathrm{VL}$ \\
\hline $\mathrm{C}_{3}$ & $\mathrm{~L}$ & $\mathrm{VL}$ & - & $\mathrm{VL}$ \\
\hline $\mathrm{C}_{4}$ & $\mathrm{VL}$ & $\mathrm{L}$ & $\mathrm{H}$ & - \\
\hline
\end{tabular}

Table 9. Numerical values of an expert opinion based on fuzzy scales

\begin{tabular}{|c|c|c|c|c|}
\hline & $\mathrm{C}_{1}$ & $\mathrm{C}_{2}$ & $\mathrm{C}_{3}$ & $\mathrm{C}_{4}$ \\
\hline $\mathrm{C}_{1}$ & $(0,0,0)$ & $(0,0.0 .25)$ & $(0,0.25,0.5)$ & $(0,0.0 .25)$ \\
\hline $\mathrm{C}_{2}$ & $(0.5,0.75,1)$ & $(0,0,0)$ & $(0.75,1,1)$ & $(0,0.25,0.5)$ \\
\hline $\mathrm{C}_{3}$ & $(0.25,0.5,0.75)$ & $(0.75,1,1)$ & $(0,0,0)$ & $(0,0.25,0.5)$ \\
\hline $\mathrm{C}_{4}$ & $(0,0.25,0.5)$ & $(0.25,0.5,0.75)$ & $(0.5,0.75,1)$ & $(0,0,0)$ \\
\hline
\end{tabular}

Table 10. The non-fuzzy value of matrix by the CFCS method

\begin{tabular}{|c|c|c|c|c|}
\hline & $\mathrm{C}_{1}$ & $\mathrm{C}_{2}$ & $\mathrm{C}_{3}$ & $\mathrm{C}_{4}$ \\
\hline $\mathrm{C}_{1}$ & 0 & 0.0333 & 0.2667 & 0.0333 \\
\hline $\mathrm{C}_{2}$ & 0.7333 & 0 & 0.9667 & 0.2667 \\
\hline $\mathrm{C}_{3}$ & 0.5 & 0.9667 & 0 & 0.2667 \\
\hline $\mathrm{C}_{4}$ & 0.2667 & 0.5 & 0.7333 & 0 \\
\hline
\end{tabular}


Table 11 . The primary direct relations matrix

\begin{tabular}{|c|c|c|c|c|}
\hline & $\mathrm{C}_{1}$ & $\mathrm{C}_{2}$ & $\mathrm{C}_{3}$ & $\mathrm{C}_{4}$ \\
\hline $\mathrm{C}_{1}$ & 0 & 0.146 & 0.237 & 0.185 \\
\hline $\mathrm{C}_{2}$ & 0.646 & 0 & 0.236 & 0.168 \\
\hline $\mathrm{C}_{3}$ & 0.328 & 0.774 & 0 & 0.235 \\
\hline $\mathrm{C}_{4}$ & 0.257 & 0.098 & 0.718 & 0 \\
\hline
\end{tabular}

Table 12. The normalized direct relations matrix

\begin{tabular}{|c|c|c|c|c|}
\hline & $\mathrm{C}_{1}$ & $\mathrm{C}_{2}$ & $\mathrm{C}_{3}$ & $\mathrm{C}_{4}$ \\
\hline $\mathrm{C}_{1}$ & 0 & 0.1092 & 0.1773 & 0.1384 \\
\hline $\mathrm{C}_{2}$ & 0.4832 & 0 & 0.1765 & 0.1257 \\
\hline $\mathrm{C}_{3}$ & 0.2453 & 0.5789 & 0 & 0.1758 \\
\hline $\mathrm{C}_{4}$ & 0.1922 & 0.0733 & 0.537 & 0 \\
\hline
\end{tabular}

Table 13. The overall relations matrix

\begin{tabular}{|c|c|c|c|c|}
\hline & $\mathrm{C}_{1}$ & $\mathrm{C}_{2}$ & $\mathrm{C}_{3}$ & $\mathrm{C}_{4}$ \\
\hline $\mathrm{C}_{1}$ & 0.4346 & 0.4896 & 0.5304 & 0.3533 \\
\hline $\mathrm{C}_{2}$ & 1.0052 & 0.546 & 0.6958 & 0.4556 \\
\hline $\mathrm{C}_{3}$ & 1.099 & 1.1611 & 0.7224 & 0.6007 \\
\hline $\mathrm{C}_{4}$ & 0.9397 & 0.831 & 1.0779 & 0.4239 \\
\hline
\end{tabular}

Table 14. Values of $D, R, D+R, D-R$

\begin{tabular}{|c|c|c|c|c|c|}
\hline BSC aspects & $D$ & $R$ & $D+R$ & $D-R$ & Group \\
\hline $\mathrm{C}_{1}$ & 1.8079 & 3.4785 & 5.2865 & -1.6706 & Effect \\
\hline $\mathrm{C}_{2}$ & 2.7026 & 3.0277 & 5.7303 & -0.3251 & Effect \\
\hline $\mathrm{C}_{3}$ & 3.5833 & 3.0265 & 6.6098 & 0.5568 & Cause \\
\hline$C_{4}$ & 3.2725 & 1.8335 & 5.106 & 1.4389 & Cause \\
\hline
\end{tabular}

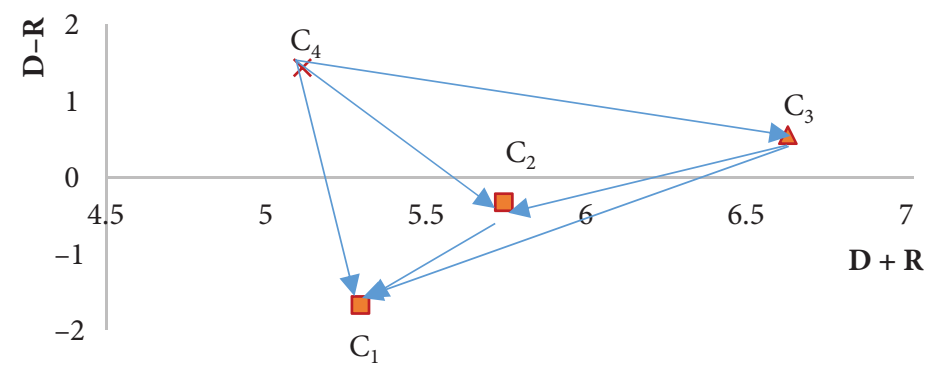

Figure 3. The position of BSC aspects based on the two indexes $D+R$ and $D-R$ 
As can be seen, the learning and growth and internal processes aspects are located in the positive region of the " $D-R$ " axis, known as a causal factor in terms of the type of relation. The finance and students' aspects are located in the negative part of the " $D-R$ " axis which indicates that they are the effects in the relationships. As noted in Section 3, the normalized values of the direct relations matrix can be used as an estimate of internal weight between factors in the super matrix of ANP model. The results of calculations are reported in Table 15.

Table 15. The internal weights of the main criteria based on the overall relations matrix

\begin{tabular}{|c|c|c|c|c|}
\hline & $\mathrm{C}_{1}$ & $\mathrm{C}_{2}$ & $\mathrm{C}_{3}$ & $\mathrm{C}_{4}$ \\
\hline $\mathrm{C}_{1}$ & 0.1249 & 0.1617 & 0.1753 & 0.1927 \\
\hline $\mathrm{C}_{2}$ & 0.2890 & 0.1803 & 0.2299 & 0.2485 \\
\hline $\mathrm{C}_{3}$ & 0.3159 & 0.3835 & 0.2387 & 0.3276 \\
\hline $\mathrm{C}_{4}$ & 0.2701 & 0.2745 & 0.3562 & 0.2312 \\
\hline
\end{tabular}

\subsection{Relations among indices of related to each of BSC aspects}

The initial direct relations matrix is formed based on indicators related to financial aspect (Table 16). In addition, the normalized direct relations matrix and overall relations matrix are determined based on Eqs (1) and (2), and they are demonstrated in Tables 17 and 18.

Table 16. The primary direct relations matrix based on financial aspect

\begin{tabular}{|c|c|c|c|c|}
\hline & $\mathrm{C}_{11}$ & $\mathrm{C}_{12}$ & $\mathrm{C}_{13}$ & $\mathrm{C}_{14}$ \\
\hline $\mathrm{C}_{11}$ & 0 & 0.4909 & 0.4581 & 0.2949 \\
\hline $\mathrm{C}_{12}$ & 0.2647 & 0 & 0.322 & 0.4422 \\
\hline $\mathrm{C}_{13}$ & 0.5609 & 0.5398 & 0 & 0.402 \\
\hline $\mathrm{C}_{14}$ & 0.479 & 0.842 & 0.3429 & 0 \\
\hline
\end{tabular}

Table 17. The normalized direct relations matrix based on financial aspect

\begin{tabular}{|c|c|c|c|c|}
\hline & $\mathrm{C}_{11}$ & $\mathrm{C}_{12}$ & $\mathrm{C}_{13}$ & $\mathrm{C}_{14}$ \\
\hline $\mathrm{C}_{11}$ & 0 & 0.2621 & 0.2447 & 0.1575 \\
\hline $\mathrm{C}_{12}$ & 0.1413 & 0 & 0.172 & 0.2361 \\
\hline $\mathrm{C}_{13}$ & 0.2995 & 0.2883 & 0 & 0.2146 \\
\hline $\mathrm{C}_{14}$ & 0.2558 & 0.4496 & 0.1831 & 0 \\
\hline
\end{tabular}

Table 18. The overall relations matrix based on financial aspect

\begin{tabular}{|c|c|c|c|c|}
\hline & $\mathrm{C}_{11}$ & $\mathrm{C}_{12}$ & $\mathrm{C}_{13}$ & $\mathrm{C}_{14}$ \\
\hline $\mathrm{C}_{11}$ & 0.4188 & 0.7773 & 0.578 & 0.5311 \\
\hline $\mathrm{C}_{12}$ & 0.4939 & 0.5088 & 0.4786 & 0.5368 \\
\hline $\mathrm{C}_{13}$ & 0.7212 & 0.891 & 0.4458 & 0.6344 \\
\hline $\mathrm{C}_{14}$ & 0.717 & 1.0403 & 0.6278 & 0.4933 \\
\hline
\end{tabular}


Moreover, the results of calculations of the $D+R$ and $D-R$ in order to draw cause-effect chart, based on the financial indicators, are presented in Table 19.

Table 19. Values of $D, R, D+R, D-R$ according to financial aspect

\begin{tabular}{|c|c|c|c|c|c|}
\hline $\begin{array}{c}\text { Financial } \\
\text { aspect }\end{array}$ & $D$ & $R$ & $D+R$ & $D-R$ & Group \\
\hline $\mathrm{C}_{11}$ & 2.305 & 2.351 & 4.656 & -0.046 & Effect \\
\hline$C_{12}$ & 2.018 & 3.218 & 5.235 & -1.200 & Effect \\
\hline $\mathrm{C}_{13}$ & 2.693 & 2.130 & 4.823 & 0.562 & Cause \\
\hline$C_{14}$ & 2.878 & 2.196 & 5.074 & 0.683 & Cause \\
\hline
\end{tabular}

Accordingly, the cause-effect graph, based on financial indicators, is provided in Figure 4.

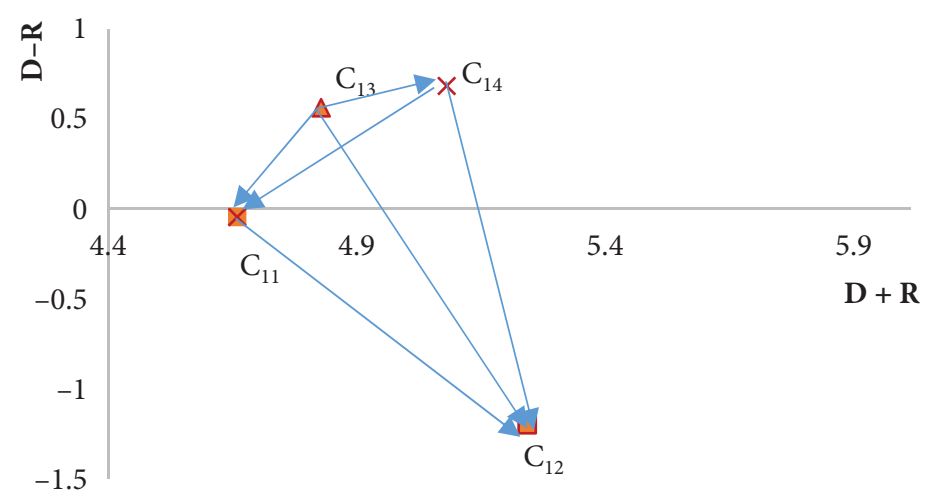

Figure 4. The cause-effect graph related to financial indicators

Educational income and reduction costs'indicators are located in the positive region of the " $D-R$ " axis, known as a causal factor, in terms of the type of relationship, according to Figure 4, the annual income growth and the rate of return on capital are located in the negative part of the " $D-R$ " axis which indicates impact being them in the relations. The calculations are performed for the other 3 indicators. Tables 20-22 represents the overall-relationships matrix, $D-R$ and $D+R$. Also, the cause-effect graph is demonstrated in Figures 5-7 for student, internal processes and learning and growth aspects, respectively.

Table 20. Values of the overall relations matrix, $D-R$ and $D+R$

\begin{tabular}{|c|c|c|c|c|c|c|c|c|c|c|c|}
\hline $\begin{array}{c}\text { Students' } \\
\text { aspect }\end{array}$ & $\mathrm{C}_{21}$ & $\mathrm{C}_{22}$ & $\mathrm{C}_{23}$ & $\mathrm{C}_{24}$ & $\mathrm{C}_{25}$ & $\mathrm{C}_{26}$ & $D$ & $R$ & $D+R$ & $D-R$ & Group \\
\hline $\mathrm{C}_{21}$ & 0.421 & 0.511 & 0.462 & 0.588 & 0.339 & 0.140 & 2.464 & 3.01 & 5.471 & -0.542 & Effect \\
\hline $\mathrm{C}_{22}$ & 0.554 & 0.293 & 0.366 & 0.516 & 0.347 & 0.150 & 2.228 & 2.24 & 4.470 & -0.014 & Effect \\
\hline $\mathrm{C}_{23}$ & 0.552 & 0.396 & 0.265 & 0.502 & 0.360 & 0.113 & 2.191 & 2.05 & 4.246 & 0.136 & Cause \\
\hline $\mathrm{C}_{24}$ & 0.548 & 0.440 & 0.365 & 0.360 & 0.358 & 0.131 & 2.204 & 2.85 & 5.056 & -0.647 & Effect \\
\hline $\mathrm{C}_{25}$ & 0.538 & 0.378 & 0.389 & 0.532 & 0.233 & 0.115 & 2.187 & 1.89 & 4.083 & 0.2921 & Cause \\
\hline $\mathrm{C}_{26}$ & 0.391 & 0.2215 & 0.2064 & 0.3517 & 0.2564 & 0.0589 & 1.4859 & 0.710 & 2.196 & 0.7758 & Cause \\
\hline
\end{tabular}




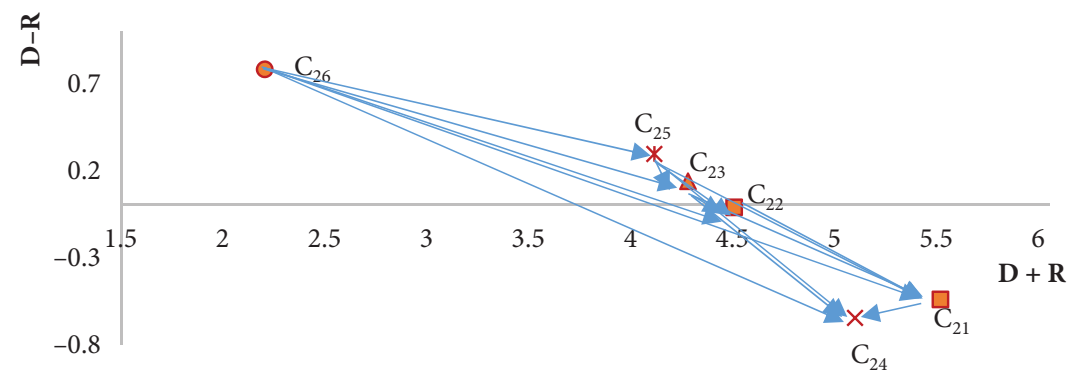

Figure 5. The cause-effect graph related to student indicators

Table 21. Values of the overall relations matrix, $D-R$ and $D+R$ based on internal processes aspect

\begin{tabular}{|c|c|c|c|c|c|c|c|c|c|c|}
\hline $\begin{array}{c}\text { Internal } \\
\text { processes' } \\
\text { aspect }\end{array}$ & $\mathrm{C}_{31}$ & $\mathrm{C}_{32}$ & $\mathrm{C}_{33}$ & $\mathrm{C}_{34}$ & $\mathrm{C}_{35}$ & $D$ & $R$ & $D+R$ & $D-R$ & Group \\
\hline $\mathrm{C}_{31}$ & 0.2957 & 0.3095 & 0.2789 & 0.4009 & 0.4005 & 1.6856 & 2.2235 & 3.909 & -0.538 & Effect \\
\hline $\mathrm{C}_{32}$ & 0.6781 & 0.3242 & 0.4624 & 0.597 & 0.5423 & 2.604 & 1.6059 & 4.210 & 0.998 & Cause \\
\hline $\mathrm{C}_{33}$ & 0.2054 & 0.2039 & 0.1024 & 0.2032 & 0.1596 & 0.8745 & 1.4451 & 2.320 & -0.571 & Effect \\
\hline $\mathrm{C}_{34}$ & 0.5063 & 0.3531 & 0.3403 & 0.2665 & 0.3495 & 1.8158 & 1.8901 & 3.706 & -0.074 & Effect \\
\hline $\mathrm{C}_{35}$ & 0.5381 & 0.4152 & 0.261 & 0.4224 & 0.2697 & 1.9063 & 1.7216 & 3.628 & 0.185 & Cause \\
\hline
\end{tabular}

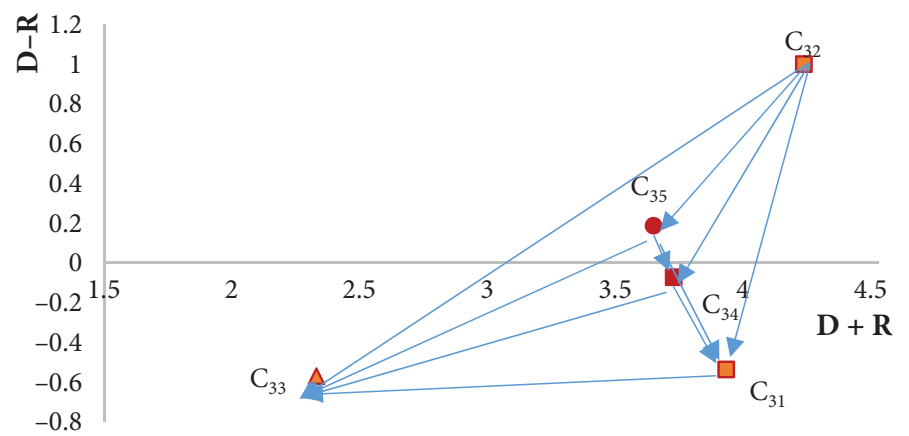

Figure 6. The cause-effect graph related to internal processes indicators

Table 22. Values of the overall relations matrix, $D-R$ and $D+R$ based on learning and growth aspect

\begin{tabular}{|c|c|c|c|c|c|c|c|c|c|c|c|}
\hline $\begin{array}{c}\text { Learning } \\
\text { and } \\
\text { growth } \\
\text { aspect }\end{array}$ & $\mathrm{C}_{41}$ & $\mathrm{C}_{42}$ & $\mathrm{C}_{43}$ & $\mathrm{C}_{44}$ & $\mathrm{C}_{45}$ & $\mathrm{C}_{46}$ & $D$ & $R$ & $D+R$ & $D-R$ & Group \\
\hline $\mathrm{C}_{41}$ & 0.8291 & 1.0425 & 0.9862 & 0.9442 & 0.7822 & 0.9913 & 5.576 & 4.967 & 10.542 & 0.609 & Cause \\
\hline $\mathrm{C}_{42}$ & 0.7799 & 0.6721 & 0.7607 & 0.7106 & 0.5908 & 0.7599 & 4.274 & 5.259 & 9.533 & -0.985 & Effect \\
\hline $\mathrm{C}_{43}$ & 0.8318 & 0.852 & 0.6682 & 0.7748 & 0.5787 & 0.8691 & 4.575 & 4.857 & 9.431 & -0.282 & Effect \\
\hline $\mathrm{C}_{44}$ & 0.9367 & 1.0021 & 0.8997 & 0.7139 & 0.6881 & 0.9091 & 5.150 & 4.638 & 9.787 & 0.512 & Cause \\
\hline $\mathrm{C}_{45}$ & 0.8523 & 0.9775 & 0.8237 & 0.8455 & 0.5452 & 0.8655 & 4.910 & 3.703 & 8.613 & 1.206 & Cause \\
\hline $\mathrm{C}_{46}$ & 0.7371 & 0.7129 & 0.7179 & 0.6486 & 0.5183 & 0.5882 & 3.923 & 4.983 & 8.906 & -1.060 & Effect \\
\hline
\end{tabular}




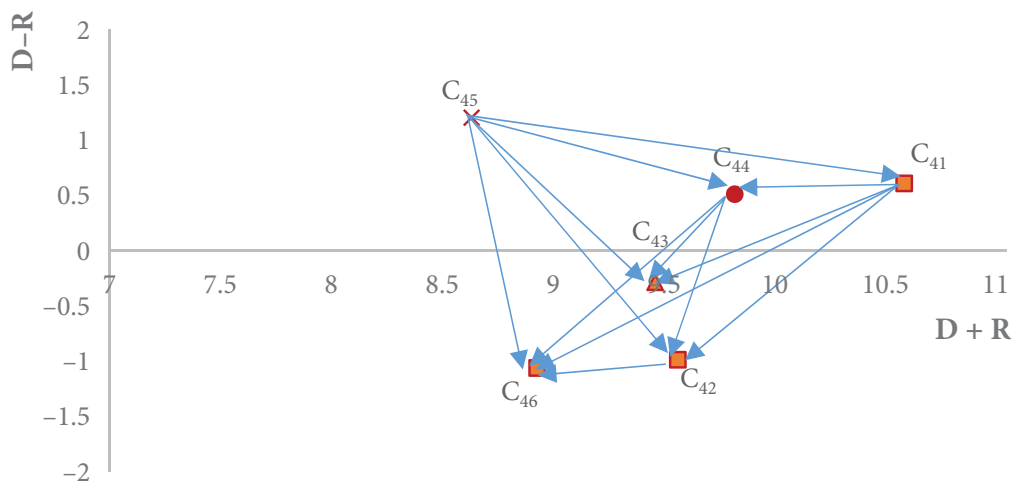

Figure 7. The cause-effect graph related learning and growth indicators

\subsection{Weights or priority vector}

In this section, the weights or priority vectors are established based on the paired comparison matrix. The comparisons are made in these matrices, based on AHP or ANP techniques, which the weight vector is the results of these matrices. Hence, the importance of each of the BSC aspects in relation to the goal (performance evaluation of the university) and the importance of each of the indicators related to each aspect of the BSC will be determined by pairwise comparisons. After determining the BSC aspects and issues indices, the weight of each of the aspects and indicators should be calculated relative to the upper node separately.

In the first step, the pairwise comparison is conducted based on the four BSC main aspects with the aim of achieving their relative weight in comparison to each other and relative to the target node (performance evaluation of university).

After aggregation of experts' opinions (Table 23), the defuzzification of judgments by the CFCS method and based on Eqs (7) to (14), and after ensuring that the consistency of experts' opinions, the weight of each component and inconsistency index are calculated with regard to Eqs (19) to (22).

Table 23. Compilation of experts' paired comparison for BSC aspects (First Level)

\begin{tabular}{|c|c|c|c|c|}
\hline Goal & $\mathrm{C}_{1}$ & $\mathrm{C}_{2}$ & $\mathrm{C}_{3}$ & $\mathrm{C}_{4}$ \\
\hline $\mathrm{C}_{1}$ & $(1,1,1)$ & $(2.874,3.170,3.446)$ & $(4.925,6.010,6.776)$ & $(1.065,1.313,1.669)$ \\
\hline $\mathrm{C}_{2}$ & $(0.290,0.315,0.348)$ & $(1,1,1)$ & $(3.752,4.762,5.769)$ & $(0.263,0.313,0.39)$ \\
\hline $\mathrm{C}_{3}$ & $(0.148,0.166,0.203)$ & $(0.173,0.210,0.267)$ & $(1,1,1)$ & $(0.191,0.237,0.313)$ \\
\hline $\mathrm{C}_{4}$ & $(0.599,0.762,0.939)$ & $(2.564,3.2,3.797)$ & $(3.194,4.222,5.238)$ & $(1,1,1)$ \\
\hline
\end{tabular}

The non-fuzzy final matrix by CFCS method, the consistency index, and the final weight of the main BSC indicators are presented in Table 24.

In the next step, the weights of each of the BSC indicators are calculated with the aim of obtaining their relative weight in comparison with each other. The results of these comparisons are reported in Tables 25 to 32. 
Table 24. The weight of the main BSC aspects relative to the issue goal

\begin{tabular}{|c|c|c|c|c|c|}
\hline Goal & $\mathrm{C}_{1}$ & $\mathrm{C}_{2}$ & $\mathrm{C}_{3}$ & $\mathrm{C}_{4}$ & Weight \\
\hline $\mathrm{C}_{1}$ & 1.000 & 3.166 & 5.899 & 1.338 & 0.4242 \\
\hline $\mathrm{C}_{2}$ & 0.316 & 1.000 & 4.722 & 0.314 & 0.1665 \\
\hline $\mathrm{C}_{3}$ & 0.167 & 0.211 & 1.000 & 0.238 & 0.0598 \\
\hline $\mathrm{C}_{4}$ & 0.766 & 3.195 & 4.196 & 1.000 & 0.3495 \\
\hline \multicolumn{6}{|c}{$\mathrm{CR}=0.0605<0.08$} \\
\hline
\end{tabular}

Table 25. Compilation of experts' paired comparison for the financial indicators

\begin{tabular}{|c|c|c|c|c|}
\hline Financial & $\mathrm{C}_{11}$ & $\mathrm{C}_{12}$ & $\mathrm{C}_{13}$ & $\mathrm{C}_{14}$ \\
\hline $\mathrm{C}_{11}$ & $(1,1,1)$ & $(1.414,1.721,2.048)$ & $(0.253,0.297,0.364)$ & $(0.157,0.187,0.231)$ \\
\hline $\mathrm{C}_{12}$ & $(0.488,0.581,0.707)$ & $(1,1,1)$ & $(0.199,0.254,0.366)$ & $(0.133,0.154,0.183)$ \\
\hline $\mathrm{C}_{13}$ & $(2.748,3.367,3.954)$ & $(2.731,3.931,5.034)$ & $(1,1,1)$ & $(1.231,1.571,1.931)$ \\
\hline $\mathrm{C}_{14}$ & $(4.338,5.348,6.355)$ & $(5.451,6.478,7.496)$ & $(0.518,0.636,0.812)$ & $(1,1,1)$ \\
\hline
\end{tabular}

Table 26. Weight of indicators related to the financial aspect

\begin{tabular}{|c|c|c|c|c|c|}
\hline Financial & $\mathrm{C}_{11}$ & $\mathrm{C}_{12}$ & $\mathrm{C}_{13}$ & $\mathrm{C}_{14}$ & Weight \\
\hline $\mathrm{C}_{11}$ & 1.000 & 1.731 & 0.298 & 0.187 & 0.1043 \\
\hline $\mathrm{C}_{12}$ & 0.585 & 1.000 & 0.257 & 0.155 & 0.0734 \\
\hline $\mathrm{C}_{13}$ & 3.365 & 3.907 & 1.000 & 1.583 & 0.4112 \\
\hline $\mathrm{C}_{14}$ & 5.308 & 6.406 & 0.643 & 1.000 & 0.4111 \\
\hline \multicolumn{6}{|c}{$\mathrm{CR}=0.05<0.08$} \\
\hline
\end{tabular}

Table 27. Compilation of experts' paired comparison for the students indicators

\begin{tabular}{|c|c|c|c|c|c|c|}
\hline $\begin{array}{c}\text { Stu- } \\
\text { dents }\end{array}$ & $\mathrm{C}_{21}$ & $\mathrm{C}_{22}$ & $\mathrm{C}_{23}$ & $\mathrm{C}_{24}$ & $\mathrm{C}_{25}$ & $\mathrm{C}_{26}$ \\
\hline $\mathrm{C}_{21}$ & $(1,1,1)$ & $\begin{array}{c}(2.144,2.569 \\
2.996)\end{array}$ & $\begin{array}{c}(3.383,4.415 \\
5.433)\end{array}$ & $\begin{array}{c}(0.158,0.188 \\
0.232)\end{array}$ & $\begin{array}{c}(1.813,2.190 \\
2.561)\end{array}$ & $\begin{array}{c}(2.653,3.277 \\
3.277)\end{array}$ \\
\hline $\mathrm{C}_{22}$ & $\begin{array}{c}(0.334,0.389 \\
0.467)\end{array}$ & $(1,1,1)$ & $\begin{array}{c}(4.166,5.171 \\
6.175)\end{array}$ & $\begin{array}{c}(0.173,0.209 \\
0.265)\end{array}$ & $\begin{array}{c}(2.232,2.817 \\
3.402)\end{array}$ & $\begin{array}{c}(2.670,3.120 \\
3.542)\end{array}$ \\
\hline $\mathrm{C}_{23}$ & $\begin{array}{c}(0.184,0.227 \\
0.296)\end{array}$ & $\begin{array}{c}(0.162,0.193, \\
0.240)\end{array}$ & $(1,1,1)$ & $\begin{array}{c}(0.149,0.176 \\
0.214)\end{array}$ & $\begin{array}{c}(1.090,1.349, \\
1.653)\end{array}$ & $\begin{array}{c}(2.058,2.569 \\
3.120)\end{array}$ \\
\hline $\mathrm{C}_{24}$ & $\begin{array}{c}(4.310,5.326 \\
6.337)\end{array}$ & $\begin{array}{c}(3.776,4.782 \\
5.785)\end{array}$ & $\begin{array}{c}(4.674,5.697 \\
6.713)\end{array}$ & $(1,1,1)$ & $\begin{array}{c}(4.021,5.086 \\
6.125)\end{array}$ & $\begin{array}{c}(4.542,5.571 \\
6.592)\end{array}$ \\
\hline $\mathrm{C}_{25}$ & $\begin{array}{c}(0.390,0.457 \\
0.552)\end{array}$ & $\begin{array}{c}(0.294,0.355 \\
0.448)\end{array}$ & $\begin{array}{c}(0.605,0.741 \\
0.917)\end{array}$ & $\begin{array}{c}(0.163,0.197 \\
0.249)\end{array}$ & $(1,1,1)$ & $\begin{array}{c}(0.683,0.758 \\
0.896)\end{array}$ \\
\hline $\mathrm{C}_{26}$ & $\begin{array}{c}(0.247,0.305 \\
0.377)\end{array}$ & $\begin{array}{c}(0.282,0.320 \\
0.374)\end{array}$ & $\begin{array}{c}(0.320,0.389 \\
0.486)\end{array}$ & $\begin{array}{c}(0.152,0.179 \\
0.220)\end{array}$ & $\begin{array}{c}(1.116,1.320 \\
1.463)\end{array}$ & $(1,1,1)$ \\
\hline
\end{tabular}


Table 28. Weight of indicators related to the students aspect

\begin{tabular}{|c|c|c|c|c|c|c|c|}
\hline Students & $\mathrm{C}_{21}$ & $\mathrm{C}_{22}$ & $\mathrm{C}_{23}$ & $\mathrm{C}_{24}$ & $\mathrm{C}_{25}$ & $\mathrm{C}_{26}$ & Weight \\
\hline $\mathrm{C}_{21}$ & 1.000 & 2.575 & 4.381 & 0.188 & 2.196 & 3.311 & 0.1915 \\
\hline $\mathrm{C}_{22}$ & 0.391 & 1.000 & 5.117 & 0.210 & 2.416 & 3.656 & 0.1515 \\
\hline $\mathrm{C}_{23}$ & 0.228 & 0.194 & 1.000 & 0.176 & 1.363 & 2.587 & 0.0665 \\
\hline $\mathrm{C}_{24}$ & 5.266 & 4.739 & 5.624 & 1.000 & 5.026 & 5.501 & 0.4789 \\
\hline $\mathrm{C}_{25}$ & 0.459 & 0.420 & 0.748 & 0.197 & 1.000 & 0.765 & 0.0598 \\
\hline $\mathrm{C}_{26}$ & 0.306 & 0.274 & 0.392 & 0.180 & 1.313 & 1.000 & 0.0518 \\
\hline \multicolumn{7}{|c|}{$\mathrm{CR}=0.0973<0.1$} \\
\hline
\end{tabular}

Table 29. Compilation of experts' paired comparison for the internal processes indicators

\begin{tabular}{|c|c|c|c|c|c|}
\hline $\begin{array}{c}\text { Internal } \\
\text { processes }\end{array}$ & $\mathrm{C}_{31}$ & $\mathrm{C}_{32}$ & $\mathrm{C}_{33}$ & $\mathrm{C}_{34}$ & $\mathrm{C}_{35}$ \\
\hline $\mathrm{C}_{31}$ & $(1,1,1)$ & $(2,2.397,2.877)$ & $\begin{array}{c}0.381,0.499, \\
0.660)\end{array}$ & $\begin{array}{c}(0.679,0.929, \\
1.259)\end{array}$ & $\begin{array}{c}0.428,0.559, \\
0.758)\end{array}$ \\
\hline $\mathrm{C}_{32}$ & $(0.348,0.417,5)$ & $(1,1,1)$ & $\begin{array}{c}0.338,0.431, \\
0.574)\end{array}$ & $\begin{array}{c}0.577,0.812, \\
1.246)\end{array}$ & $\begin{array}{c}0.621,0.775, \\
1.058)\end{array}$ \\
\hline $\mathrm{C}_{33}$ & $\begin{array}{c}(1.516,2.003, \\
2.625)\end{array}$ & $\begin{array}{c}(1.741,2.319, \\
2.961)\end{array}$ & $(1,1,1)$ & $\begin{array}{c}0.803,0.985, \\
1.175)\end{array}$ & $\begin{array}{c}(0.591,0.854, \\
1.260)\end{array}$ \\
\hline $\mathrm{C}_{34}$ & $\begin{array}{c}(0.794,1.076, \\
1.473)\end{array}$ & $\begin{array}{c}(0.803,1.231, \\
1.732)\end{array}$ & $\begin{array}{c}(0.851,1.015, \\
1.246)\end{array}$ & $(1,1,1)$ & $\begin{array}{c}0.654,0.890, \\
1.162)\end{array}$ \\
\hline $\mathrm{C}_{35}$ & $\begin{array}{c}(1.320,1.788, \\
2.337)\end{array}$ & $\begin{array}{c}(0.946,1.291, \\
1.609)\end{array}$ & $\begin{array}{c}(0.793,1.171, \\
1.692)\end{array}$ & $\begin{array}{c}0.860,1.123, \\
1.530)\end{array}$ & $(1,1,1)$ \\
\hline
\end{tabular}

Table 30. Weight of indicators related to the internal processes aspect

\begin{tabular}{|c|c|c|c|c|c|c|}
\hline $\begin{array}{c}\text { Internal } \\
\text { processes }\end{array}$ & $\mathrm{C}_{31}$ & $\mathrm{C}_{32}$ & $\mathrm{C}_{33}$ & $\mathrm{C}_{34}$ & $\mathrm{C}_{35}$ & Weight \\
\hline $\mathrm{C}_{31}$ & 1.000 & 2.545 & 0.508 & 0.956 & 0.574 & 0.1827 \\
\hline $\mathrm{C}_{32}$ & 0.391 & 1.000 & 0.439 & 0.864 & 0.804 & 0.1279 \\
\hline $\mathrm{C}_{33}$ & 2.010 & 2.290 & 1.000 & 0.992 & 0.896 & 0.2511 \\
\hline $\mathrm{C}_{34}$ & 1.111 & 1.262 & 1.033 & 1.000 & 0.907 & 0.1973 \\
\hline $\mathrm{C}_{35}$ & 1.798 & 1.294 & 1.216 & 1.163 & 1.000 & 0.241 \\
\hline \multicolumn{7}{|c|}{$\mathrm{CR}=0.0606<0.1$} \\
\hline
\end{tabular}

Table 31. Compilation of experts' paired comparison for the learning and growth indicators

\begin{tabular}{|c|c|c|c|c|c|c|}
\hline \begin{tabular}{|c|} 
Learning \\
and growth
\end{tabular} & $\mathrm{C}_{41}$ & $\mathrm{C}_{42}$ & $\mathrm{C}_{43}$ & $\mathrm{C}_{44}$ & $\mathrm{C}_{45}$ & $\mathrm{C}_{46}$ \\
\hline $\mathrm{C}_{41}$ & $(1,1,1)$ & $\begin{array}{c}(0.53,0.66 \\
1.04)\end{array}$ & $\begin{array}{c}(1.64,2.04, \\
2.51)\end{array}$ & $\begin{array}{c}(0.34,0.46 \\
0.66)\end{array}$ & $\begin{array}{c}(1.94,2.49, \\
3.06)\end{array}$ & $\begin{array}{c}(3.42,4.21, \\
5.10)\end{array}$ \\
\hline $\mathrm{C}_{42}$ & $\begin{array}{c}(0.96,1.50 \\
1.99) \\
\end{array}$ & $(1,1,1)$ & $\begin{array}{c}(2.67,3.70, \\
4.72)\end{array}$ & $\begin{array}{c}(2.02,2.82, \\
3.68)\end{array}$ & $\begin{array}{c}(2.74,3.36, \\
3.95)\end{array}$ & $\begin{array}{c}(1.93,2.74, \\
3.60)\end{array}$ \\
\hline $\mathrm{C}_{43}$ & $\begin{array}{c}(0.39,0.49 \\
0.6)\end{array}$ & $\begin{array}{c}(0.21,0.27 \\
0.37)\end{array}$ & $(1,1,1)$ & $\begin{array}{c}(0.49,0.70 \\
0.98)\end{array}$ & $\begin{array}{c}(0.8,1.1 \\
1.23)\end{array}$ & $\begin{array}{c}(0.56,0.76, \\
1.04)\end{array}$ \\
\hline $\mathrm{C}_{44}$ & $\begin{array}{c}(1.51,2.14, \\
2.86)\end{array}$ & $\begin{array}{c}(0.27,0.35 \\
0.49)\end{array}$ & $\begin{array}{c}(1.01,1.42, \\
2.02)\end{array}$ & $(1,1,1)$ & $\begin{array}{c}(0.69,0.94, \\
1.21)\end{array}$ & $\begin{array}{c}(1.6,2.322, \\
3.28)\end{array}$ \\
\hline $\mathrm{C}_{45}$ & $\begin{array}{c}(0.32,0.401 \\
0.51)\end{array}$ & $\begin{array}{c}(0.25,0.29 \\
0.36)\end{array}$ & $\begin{array}{c}(0.81,0.99 \\
1.24)\end{array}$ & $\begin{array}{c}(0.82,1.05, \\
1.43)\end{array}$ & $(1,1,1)$ & $\begin{array}{c}(2.56,3.42, \\
4.23)\end{array}$ \\
\hline $\mathrm{C}_{46}$ & $\begin{array}{c}(0.19,0.23 \\
0.29)\end{array}$ & $\begin{array}{c}(0.27,0.36 \\
0.51)\end{array}$ & $\begin{array}{c}(0.96,1.31, \\
1.76)\end{array}$ & $\begin{array}{c}(0.30,0.43, \\
0.62)\end{array}$ & $\begin{array}{c}(0.23,0.29 \\
0.39)\end{array}$ & $(1,1,1)$ \\
\hline
\end{tabular}


Table 32. Weight of indicators related to the learning and growth aspect

\begin{tabular}{|c|c|c|c|c|c|c|c|}
\hline Learning and growth & $\mathrm{C}_{41}$ & $\mathrm{C}_{42}$ & $\mathrm{C}_{43}$ & $\mathrm{C}_{44}$ & $\mathrm{C}_{45}$ & $\mathrm{C}_{46}$ & Weight \\
\hline $\mathrm{C}_{41}$ & 1.000 & 0.701 & 2.065 & 0.477 & 2.501 & 4.174 & 0.2041 \\
\hline $\mathrm{C}_{42}$ & 1.509 & 1.000 & 3.648 & 2.831 & 3.345 & 2.753 & 0.3222 \\
\hline $\mathrm{C}_{43}$ & 0.494 & 0.273 & 1.000 & 0.720 & 1.016 & 0.781 & 0.0915 \\
\hline $\mathrm{C}_{44}$ & 2.174 & 0.359 & 1.478 & 1.000 & 0.960 & 2.385 & 0.1795 \\
\hline $\mathrm{C}_{45}$ & 0.405 & 0.298 & 1.009 & 1.087 & 1.000 & 3.384 & 0.1291 \\
\hline $\mathrm{C}_{46}$ & 0.238 & 0.370 & 1.343 & 0.439 & 0.295 & 1.000 & 0.0736 \\
\hline \multicolumn{7}{|c|}{$\mathrm{CR}=0861<0.1$} \\
\hline
\end{tabular}

\subsection{Evaluation and obtaining the final weight of the indicators}

This step consists of three sections:

- The established unweighted super matrix;

- The calculated weighted super matrix;

- The determined limited super matrix.

The unweighted super matrix is created based on results obtained from $T$-matrix by fuzzy DEMATEL technique, weights obtained from pairwise comparisons between aspects and sub-indexes and also the weight of internal relationship among the sub-indices. Then, this matrix is normalized with respect to the sum of column values, such as the $T$-matrix (weighted super matrix). Finally, the unweighted super matrix reaches to $(2 k+1)$-power $(k$ is an arbitrary number) to obtain the final weights of each index, or sub index. It is notable that the Super Decisions software has been used. The final result is given in Table 33.

In the following, the final weight of the effective indices on the performance evaluation of university is presented in Table 34 .

\subsection{Calculation of university performance}

In this section, the performance levels of the desirable indicators are evaluated by the experts in the studied university. In this study, the performance scale is applied based on Yüksel and Daugdeviren' study (2010) which is divided into different levels. Finally, after gathering experts' opinions, based on linguistic scales value, the current performance of each of the indices are evaluated at the university, then the mean of opinions is used to assess performance. Table 35 shows the average university performance for each of the indicators.

\section{Comparison analysis}

\subsection{Analysis of fuzzy DEMATEL results}

The "growth and learning" and "internal processes" are in the positive region and dedicated to the cause of the cluster, based on the results of the data analysis (Figure 3 ). The net influence matrix $(N)$ can be used for a better understanding of the position of each criterion and facilitating the interpretation and conclusion. The $N$ matrix measures the strength of the effect of each criterion on the other criteria and is calculated through the overall relations matrix $(T)$, as follows:

$$
N=N e t_{i j}=t_{i j}-t_{j i}
$$




\begin{tabular}{|c|c|c|c|c|c|c|c|c|c|c|c|c|c|c|}
\hline & & & & & & & & & & & & & ఫั & \\
\hline & รุ & 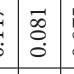 & & & & : & & & & & $\begin{array}{c}n \\
\vdots \\
\vdots \\
0\end{array}$ & 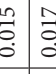 & : & $\Xi$ \\
\hline & 공 & & & & & & & & & & & 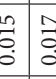 & & \\
\hline & 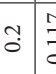 & & & & & 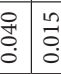 & & & & & $\begin{array}{l}0 \\
0 \\
0 \\
0\end{array}$ & 总 & : & \\
\hline & $\because$ & & & & & & & & 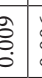 & & $\stackrel{\circ}{\circ}$ & : & : & \\
\hline$F^{7}$ & $\because$ & $\vec{a}$ & & & & $\frac{1}{0}$ & & & 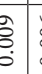 & & 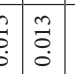 & & స్: & \\
\hline$\tilde{s}$ & $\because$ & & & & & & & & 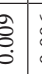 & 更 & $\begin{array}{c}0 \\
\vdots \\
\vdots \\
\vdots \\
0\end{array}$ & 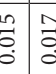 & : & \\
\hline 芯 & $\because$ & & & & & 曾 & 1 & & ठ্. & 10 & 5 & 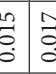 & : & \\
\hline$\hat{0}$ & $\because \Xi$ & & & ? & & 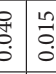 & & & & of & $\begin{array}{c}0 \\
\vdots \\
0 \\
0\end{array}$ & 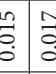 & & \\
\hline 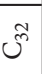 & $\because$ & 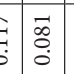 & & & & t. & & & & $\therefore$ & $\ddot{0}$ & 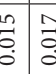 & స్ : & \\
\hline $\overrightarrow{S^{3}}$ & $\because$ & $\begin{array}{l}\overrightarrow{0} \\
\overrightarrow{0} \\
0\end{array}$ & & & & : & & & & 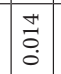 & 管 & & : & \\
\hline 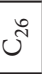 & $\because \Xi$ & 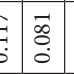 & & & & & & & 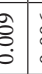 & & & 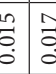 & : & \\
\hline 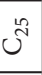 & $\because \Xi$ & 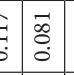 & & & & & & & & & & 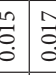 & 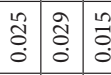 & \\
\hline$\vec{v}$ & $\because \cong$ & & & & & & & & & & $\mid$ & 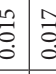 & : & \\
\hline 3 & $\because$ & & & & & & & & & & & & & \\
\hline$\tilde{j}$ & 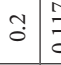 & & & & & & & & : & & & & & \\
\hline $\overrightarrow{v^{3}}$ & $\because \Xi$ & 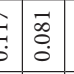 & & & & & & & & & & & & \\
\hline 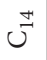 & $\because$ & & & & & & & & & & & & & \\
\hline 0 & 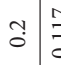 & 丞 & & & & & & & ठ্. & & 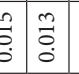 & & : & : \\
\hline 0 & $\because \Xi$ & 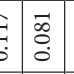 & & & & & & & & & & & & \\
\hline & $\because \Xi$ & 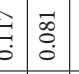 & & & & & & & & & & & & $\widetilde{\Xi}$ \\
\hline$u^{*}$ & $\because$ & $\overrightarrow{0}$ & & & & & & & & & & & & : \\
\hline & $\therefore$ & $=\frac{\vec{g}}{0}$ & & & & & & & & & & & & $\stackrel{8}{8}$ \\
\hline$\checkmark$ & $\because$ & $=\mid \vec{g}$ & & & & & & & & & & & & 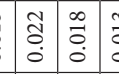 \\
\hline$v$ & $\stackrel{2}{8}$ & $=\frac{\vec{b}}{0}$ & & & & & & & & & & & & \\
\hline 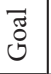 & $\because \cong$ & & & & & & & & & & & & & \\
\hline & \begin{tabular}{|l|l}
\multirow{g}{\circ}{} & 0
\end{tabular} & & & & & & & & & & & & & \\
\hline
\end{tabular}


Table 34. The final weight and ranking of BSC aspects and model indices

\begin{tabular}{|c|c|c|c|c|c|}
\hline BSC's aspects & Local weight & $\begin{array}{l}\text { Normalized } \\
\text { weight in cluster }\end{array}$ & Final weight & Rank in cluster & $\begin{array}{c}\text { Final } \\
\text { ranking }\end{array}$ \\
\hline $\mathrm{C}_{1}$ & 0.1176 & 0.2941 & 0.2941 & 2 & 2 \\
\hline $\mathrm{C}_{2}$ & 0.0818 & 0.2045 & 0.2045 & 3 & 3 \\
\hline $\mathrm{C}_{3}$ & 0.0758 & 0.1894 & 0.1894 & 4 & 4 \\
\hline $\mathrm{C}_{4}$ & 0.1248 & 0.3121 & 0.3121 & 1 & 1 \\
\hline Indicators & Local weight & $\begin{array}{c}\text { Normalized } \\
\text { weight in cluster }\end{array}$ & Final weight & Rank in cluster & $\begin{array}{l}\text { Final } \\
\text { ranking }\end{array}$ \\
\hline $\mathrm{C}_{11}$ & 0.0203 & 0.1726 & 0.0507 & 3 & 7 \\
\hline $\mathrm{C}_{12}$ & 0.0172 & 0.1463 & 0.0430 & 4 & 9 \\
\hline $\mathrm{C}_{13}$ & 0.0397 & 0.3372 & 0.0992 & 2 & 2 \\
\hline $\mathrm{C}_{14}$ & 0.0405 & 0.3439 & 0.1011 & 1 & 1 \\
\hline $\mathrm{C}_{21}$ & 0.0158 & 0.1934 & 0.0395 & 2 & 12 \\
\hline $\mathrm{C}_{22}$ & 0.0134 & 0.1637 & 0.0335 & 3 & 16 \\
\hline $\mathrm{C}_{23}$ & 0.0098 & 0.1195 & 0.0244 & 4 & 19 \\
\hline $\mathrm{C}_{24}$ & 0.0264 & 0.3230 & 0.0660 & 1 & 4 \\
\hline $\mathrm{C}_{25}$ & 0.0095 & 0.1165 & 0.0238 & 5 & 20 \\
\hline $\mathrm{C}_{26}$ & 0.0069 & 0.0839 & 0.0171 & 6 & 21 \\
\hline $\mathrm{C}_{31}$ & 0.0143 & 0.1885 & 0.0357 & 4 & 15 \\
\hline $\mathrm{C}_{32}$ & 0.0159 & 0.2092 & 0.0396 & 2 & 11 \\
\hline $\mathrm{C}_{33}$ & 0.0133 & 0.1750 & 0.0331 & 5 & 18 \\
\hline $\mathrm{C}_{34}$ & 0.0152 & 0.2009 & 0.0380 & 3 & 14 \\
\hline $\mathrm{C}_{35}$ & 0.0172 & 0.2264 & 0.0429 & 1 & 10 \\
\hline $\mathrm{C}_{41}$ & 0.0250 & 0.2000 & 0.0624 & 2 & 5 \\
\hline $\mathrm{C}_{42}$ & 0.0293 & 0.2350 & 0.0733 & 1 & 3 \\
\hline $\mathrm{C}_{43}$ & 0.0158 & 0.1266 & 0.0395 & 5 & 13 \\
\hline $\mathrm{C}_{44}$ & 0.0225 & 0.1806 & 0.0563 & 3 & 6 \\
\hline $\mathrm{C}_{45}$ & 0.0189 & 0.1512 & 0.0472 & 4 & 8 \\
\hline $\mathrm{C}_{46}$ & 0.0133 & 0.1065 & 0.0332 & 6 & 17 \\
\hline
\end{tabular}

Table 35. The performance level for each index in the university

\begin{tabular}{|l|l|c|c|}
\hline \multirow{2}{*}{ BSC's aspects } & \multicolumn{1}{|c|}{ Indicators } & $\begin{array}{c}\text { Average university } \\
\text { performance }\end{array}$ & $\begin{array}{c}\text { Ranking (In terms of } \\
\text { performance) }\end{array}$ \\
\hline \multirow{5}{*}{ Financial $\left(\mathrm{C}_{1}\right)$} & Rate of return on capital $\left(\mathrm{C}_{11}\right)$ & 0.400 & 2 \\
\cline { 2 - 4 } & Annual income growth $\left(\mathrm{C}_{12}\right)$ & 0.250 & 4 \\
\cline { 2 - 4 } & Costs reduction $\left(\mathrm{C}_{13}\right)$ & 0.450 & 1 \\
\cline { 2 - 4 } & Educational income $\left(\mathrm{C}_{14}\right)$ & 0.275 & 3 \\
\hline \multirow{3}{*}{ Students $\left(\mathrm{C}_{2}\right)$} & Students' satisfaction $\left(\mathrm{C}_{21}\right)$ & 0.600 & 2 \\
\cline { 2 - 4 } & Service quality $\left(\mathrm{C}_{22}\right)$ & 0.625 & 1 \\
\cline { 2 - 4 } & $\begin{array}{l}\text { Developing relationships with } \\
\text { students }\left(\mathrm{C}_{23}\right)\end{array}$ & 0.600 & 2 \\
\hline
\end{tabular}


End of Table 35

\begin{tabular}{|c|c|c|c|}
\hline BSC's aspects & Indicators & $\begin{array}{l}\text { Average university } \\
\text { performance }\end{array}$ & $\begin{array}{l}\text { Ranking (In terms of } \\
\text { performance) }\end{array}$ \\
\hline & $\begin{array}{l}\text { The growth of the number of } \\
\text { students }\left(C_{24}\right)\end{array}$ & 0.400 & 5 \\
\hline & Graduates' satisfaction $\left(\mathrm{C}_{25}\right)$ & 0.525 & 4 \\
\hline & Graduate employment rate $\left(\mathrm{C}_{26}\right)$ & 0.400 & 5 \\
\hline \multirow{5}{*}{$\begin{array}{l}\text { Internal } \\
\text { process }\left(\mathrm{C}_{3}\right)\end{array}$} & $\begin{array}{l}\text { Timeframe for providing services } \\
\left(\mathrm{C}_{31}\right)\end{array}$ & 0.625 & 3 \\
\hline & Information technology $\left(\mathrm{C}_{32}\right)$ & 0.675 & 2 \\
\hline & Scientific publications $\left(\mathrm{C}_{33}\right)$ & 0.725 & 1 \\
\hline & Productivity of facilities $\left(\mathrm{C}_{34}\right)$ & 0.600 & 4 \\
\hline & Standard processes $\left(\mathrm{C}_{35}\right)$ & 0.450 & 5 \\
\hline \multirow{6}{*}{$\begin{array}{l}\text { Learning and } \\
\text { growth }\left(\mathrm{C}_{4}\right)\end{array}$} & Employees and professors' skills $\left(\mathrm{C}_{41}\right)$ & 0.600 & 1 \\
\hline & $\begin{array}{l}\text { Satisfaction of employees and } \\
\text { professors }\left(C_{42}\right)\end{array}$ & 0.450 & 4 \\
\hline & Innovation in teaching $\left(\mathrm{C}_{43}\right)$ & 0.575 & 3 \\
\hline & $\begin{array}{l}\text { Professors and staffs' encouragement } \\
\left(\mathrm{C}_{44}\right)\end{array}$ & 0.450 & 4 \\
\hline & Retaining staff and professors $\left(\mathrm{C}_{45}\right)$ & 0.600 & 1 \\
\hline & Courses with new technologies $\left(\mathrm{C}_{46}\right)$ & 0.450 & 4 \\
\hline \multicolumn{2}{|c|}{ The average performance score } & \multicolumn{2}{|c|}{0.511} \\
\hline
\end{tabular}

This matrix determines the influence of the criteria on each other, if $n_{i j}$ is positive then the effect direction vector is from $C_{i}$ to $C_{j}$ and vice versa. The $N$ matrix for BSC aspects is as follows:

$$
N_{1}=\begin{gathered}
C_{1} \\
C_{1} \\
C_{2} \\
C_{3} \\
C_{4}
\end{gathered}\left[\begin{array}{cccc}
0 & -0.5156 & -0.5686 & -0.5864 \\
0.5156 & 0 & -0.4654 & -0.3754 \\
0.5686 & 0.4654 & 0 & -0.4772 \\
0.5864 & 0.3754 & 0.4772 & 0
\end{array}\right] .
$$

The effect direction vectors of the growth and learning $\left(C_{4}\right)$ and the internal processes $\left(C_{3}\right)$ aspects are toward to the aspects of impact cluster regard to the Figure 3.

Moreover, the output vectors direction from the growth and learning is toward to other aspects, because this aspect at the relationship axis is located in the highest position. This is because of the increasing priority of "growth and learning" after considering the internal link between aspects and indicators. Also, the vectors direction of growth and learning, internal processes, and students are towards to the financial aspect. Hence, at first, the growth and learning aspect should be developed, and then the internal processes and students in order to reach the expected financial results and the strategic goals of the university. The results in this section are completely adaptive with the Kaplan and Norton's (2004) strategy map. 
Therefore, the requirements of other BSC aspects must be met in order to enhance the university's performance. Apart from this, there are many gaps in comparison with the actual performance of the university which is necessary to be improved.

Also, according to Figures 4 to 7, the annual income growth is the first indicator which is very influenced by other indicators and other aspects, and the rate of return on capital, educational income and cost reduction are ranked next in order. The educational income and cost reduction indicators are in the upper part of the horizontal axis ( $D-R$ positive) and indicates the effect of these indices on other indicators in the financial sector. In the students section, the growth of the number of students is the first indicator which is very influenced by other indicators and other aspects. The students' satisfaction, service quality, relationships' development of the students, graduates' satisfaction and graduate employment rate are ranked next in order. In the internal processes section, the scientific publications is the first indicator which is very much influenced by the other indicators. The timeframe for providing service, information technology, productivity of facility, and standard processes are ranked in the next in order. In the growth and learning section, the course with new technology is the first index that is very much influenced by other indicators. The satisfaction of staff and professors, innovation in teaching, professors and staff encouragement, and employees and professors' skills are ranked in the next in order, respectively.

\subsection{Analysis of fuzzy DEMATEL-ANP results}

According to Table 34, growth and learning are recognized as the most important aspect by the experts. Therefore, the university should provide some ways to encourage its staff and professors to increase their learning and growth. Creating a performance-based reward system will cause professors and staff have an explicit goal of their activities, increases the satisfaction of them and improves the continuation activity. In addition, they are able to concentrate on this aspect from a BSC and further improve the other three aspects of the BSC.

Generally, growth and learning aspect is known as an important factor in achieving the goals of universities and higher education institutions. Faculty members and university staff must always adapt themselves to modern systems and be prepared to accept new responsibilities that require skills, capabilities, technologies, and even a new organizational structure. The growth and learning will enable the university to increase its innovation capability which is one of the vital duties of the university. Therefore, managers of higher education institutions should always consider the maintenance and development of the knowledge necessary for the students' satisfaction and attention to the organization's abilities in preserving the efficiency and effectiveness of processes in the future as an important issue in the university performance.

Also, educational income, costs reduction, satisfaction of staff and professors, the growth of the number of students, and the skills of the employees and professors are ranked from the first to the fifth, based on the obtained weights for the indicators in Table 34, respectively.

It must be noted that, the average value of the linguistic scale for the first four indices at the university under study is very low according to Table 35 . This indicates that to improve performance, the university needs to prioritize the satisfaction of its professors and staff and also the growth of the number its students. 


\subsection{Compared to current status}

Comparing the performance of the university with the specified measures and determining the distance between the current status and the goals of the university is one of the key steps in performance evaluation of this university. The strengths, weaknesses and abilities of the university is identified, and the improvement points will be determined. Therefore, the functional level of the university is compared to the target level for different indicators. The results of the comparison are shown in the Figure 8.

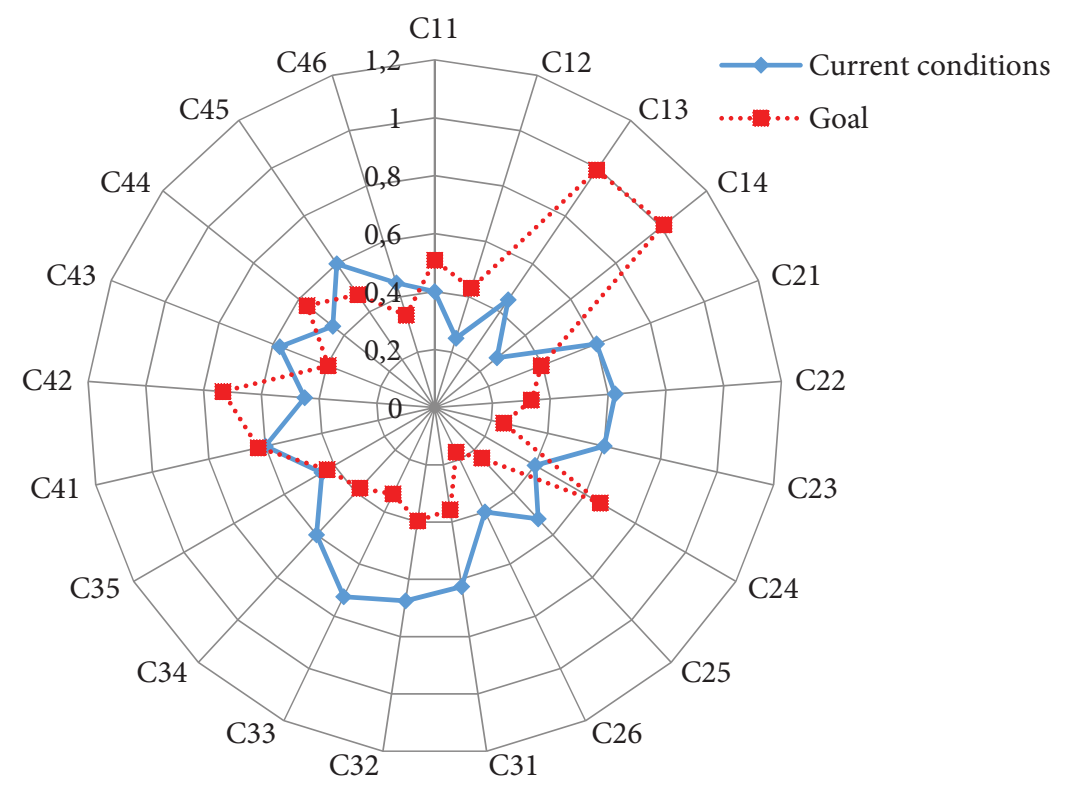

Figure 8. Comparison of the performance level of the university under study with the goal

As can be seen, the university's level of performance in indicators of rate of return on capital $\left(C_{11}\right)$, annual income growth $\left(C_{12}\right)$, costs reduction $\left(C_{13}\right)$, educational income $\left(C_{14}\right)$, the growth of the number of student $\left(C_{24}\right)$, skills of employees and professors $\left(C_{41}\right)$, satisfaction of employee and professors $\left(C_{42}\right)$, and encouragement of staff and professors $\left(C_{44}\right)$ is low and requires improvement in each of these indicators.

\section{Importance-performance matrix}

In order to prioritize improvement projects, Martilla and James (1977) presented importanceperformance analysis. On that basis, the results should be plotted in a two-dimensional network based on the indicators importance (vertical axis) and the performance level (horizontal axis). Finally, the results should be mapped on the four quarters of the coordinate system. The importance-performance diagram for the university under study is indicated in Figure 9.

As shown in Figure 9, $C_{41}$ indicator is located in the area 1. Maintaining the level of university performance is very important in this index. Indicators that are located in the area 2 
and have a lower priority in the improvement process are as follows: $C_{21}, C_{22}, C_{23}, C_{25}, C_{31}$, $C_{32}, C_{33}, C_{34}, C_{43}$ and $C_{45}$.

Indicators in the area 3 don't have high weight, and the university performance level is low for these indices. The level of university performance is low for the students located in the area 4, despite being of high importance. These indicators should be considered in the process of organizational improvement and in future programs, and they should be prioritized to the promotion of university performance. These indicators include: $C_{11}, C_{13}, C_{14}$, $C_{24}, C_{42}$ and $C_{44}$.

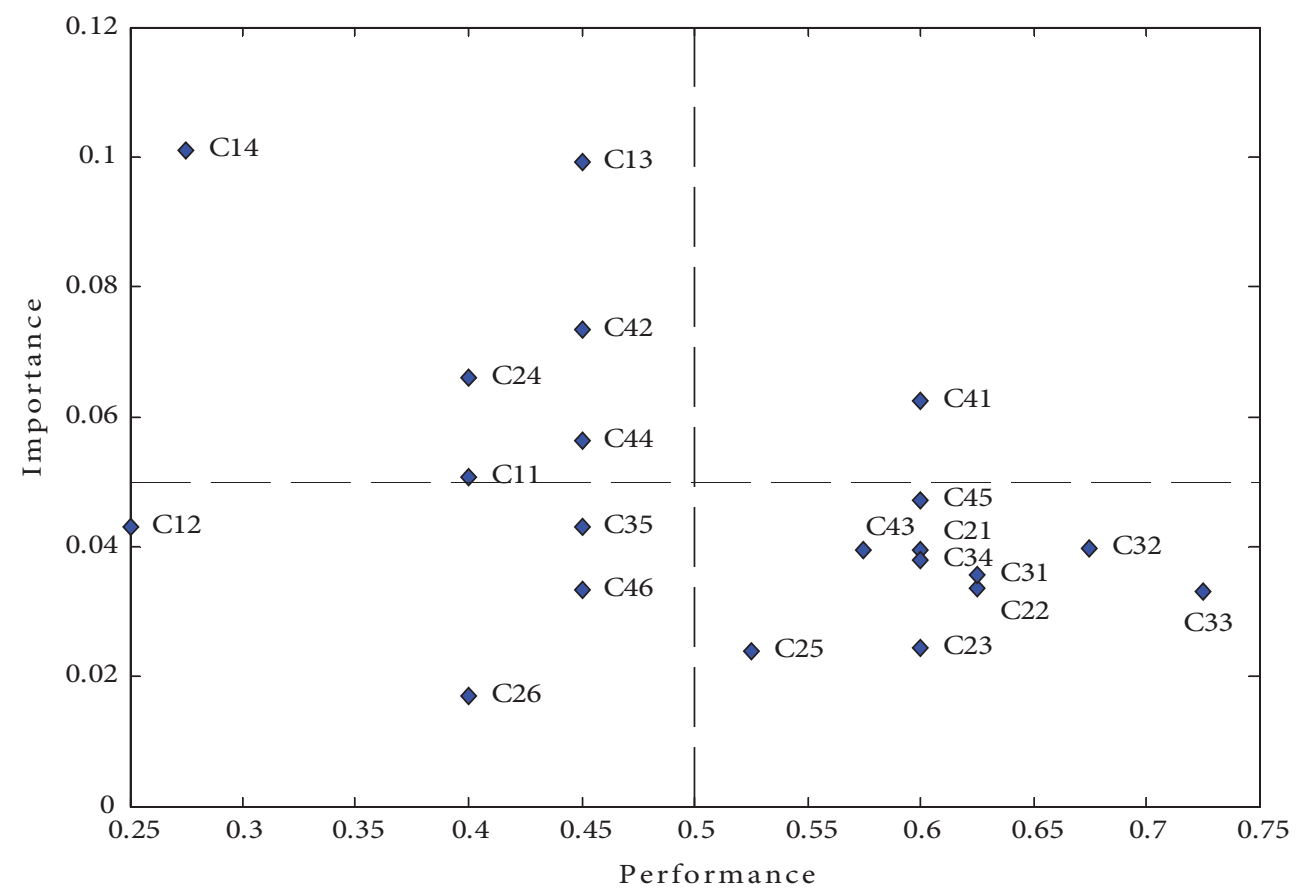

Figure 9. The importance-performance of the university under study

On the other hand, $C_{14}$ and $C_{24}$ indicators are recognized to be the most important performance indexes, while the university's performance for these indicators is at the lowest level, compared to other indices. Therefore, the growth of the number of students should be considered as one of the most important stages in improving university performance in the future in order to achieve educational income.

\section{Conclusions}

In today's global environment, organizations have a tendency to gain sustainable competitive advantages to consolidate their position in the market. The performance evaluation system is one of the tools that organizations can improve their position on market by using it. The continuous and targeted activities of universities in the field of research and technology requires understanding of the status of universities, and the existence of a performance evalu- 
ation system will be of great help in achieving this goal. The performance evaluation system, based on BSC, provides a basis for the proper, optimal and successful implementation of the organization's strategy and creates a framework for individuals to find new perspectives for their activities and organization. The BSC is a methodology that considers non-financial indicators in performance evaluation of organizations systematically. In this regard, a hybrid approach is applied based on ANP and DEMATEL under uncertainty as well-known methods of multi-criteria decision making. Hence, the cause and effect relationships between BSC aspects and indicators are investigated based on fuzzy DEMATEL technique, and the indicators importance are analyzed using the ANP fuzzy method. Then, the universities' performance is compared with the ideal level and the distance among them are determined with goals for different indices based on the obtained results. Also, the strengths, weaknesses, shortcomings and abilities of the universities are identified. Finally, the priorities of universities are determined in order to improve the performance and policies needed for future decisions by the importance-performance matrix. In this study, the collected data included only a limited number of university professors. More studies are needed for more complex performance analysis and the generalization of the results of the present study with larger size and more work record in the major universities. Also, in future studies, other MCDM approaches (Fuzzy TOPSIS, Fuzzy VIKOR and other non-ranked methods) can be used to evaluate and rank small and large universities separately.

\section{References}

Alipour, N., Sangari, M. S., \& Nazari-Shirkouhi, S. (2019). Investigating green human resource practices in the healthcare sector: A joint application of balanced scorecard and SIR method. In $201915^{\text {th }}$ Iran International Industrial Engineering Conference (IIIEC) (pp. 283-288). IEEE. https://doi.org/10.1109/IIIEC.2019.8720625

Al-Hosaini, F. F., \& Sofian, S. (2015). A review of balanced scorecard framework in higher education institution (HEIs). International Review of Management and Marketing, 5(1), 26-35.

Al Kaabi, B. R. H. (2018). The role of a balanced balanced scorecard and its role in improving the efficiency of resources. Iraqi Administrative Sciences Journal, 2(1), 50-92.

https://doi.org/10.33013/iqasj.v2n1y2018.pp50-92

Alani, F. S., Khan, M. F. R., \& Manuel, D. F. (2018). University performance evaluation and strategic mapping using balanced scorecard (BSC) Case study - Sohar University, Oman. International Journal of Educational Management, 32(4), 689-700. https://doi.org/10.1108/IJEM-05-2017-0107

Atafar, A., Shahrabi, M., \& Esfahani, M. (2013). Evaluation of university performance using BSC and ANP. Decision Science Letters, 2(4), 305-311. https://doi.org/10.5267/j.dsl.2013.06.004

Baba, Z., \& Shukor, R. A. (2003). Performance indicators for national libraries in Asia/Oceania: Preliminary proposals based on a survey of Asia/Oceania libraries. In World Library and Information Congress: $69^{\text {th }}$ IFLA General Conference and Council (pp. 1-11). IFLA, Berlin.

Baker, R. L. (2002). Evaluating quality and effectiveness: regional accreditation principles and practices. The Journal of Academic Librarianship, 28(1), 3-7. https://doi.org/10.1016/S0099-1333(01)00279-8

Beheshtinia, M. A., \& Omidi, S. (2017). A hybrid MCDM approach for performance evaluation in the banking industry. Kybernetes, 46(8), 1386-1407. https://doi.org/10.1108/K-03-2017-0105

Borujeni, M. P., \& Gitinavard, H. (2017). Evaluating the sustainable mining contractor selection problems: An imprecise last aggregation preference selection index method. Journal of Sustainable Mining, 16(4), 207-218. https://doi.org/10.1016/j.jsm.2017.12.006 
Chen, S.-H., Yang, C.-C., \& Shiau, J.-Y. (2006). The application of balanced scorecard in the performance evaluation of higher education. The TQM Magazine, 18(2), 190-205. https://doi.org/10.1108/09544780610647892

Chen, S. H., Wang, H. H., \& Yang, K. J. (2009). Establishment and application of performance measure indicators for universities. The TQM Journal, 21(3), 220-235. https://doi.org/10.1108/17542730910953004

Dai, L., \& Li, J. (2016). Study on the quality of private university education based on analytic hierarchy process and fuzzy comprehensive evaluation method1. Journal of Intelligent \& Fuzzy Systems, 31(4), 2241-2247. https://doi.org/10.3233/JIFS-169064

Dinçer, H., Hacıoğlu, Ü., \& Yüksel, S. (2017). Balanced scorecard based performance measurement of European airlines using a hybrid multicriteria decision making approach under the fuzzy environment. Journal of Air Transport Management, 63, 17-33.

https://doi.org/10.1016/j.jairtraman.2017.05.005

Ding, L., \& Zeng, Y. (2015). Evaluation of Chinese higher education by TOPSIS and IEW - The case of 68 universities belonging to the Ministry of Education in China. China Economic Review, 36, 341-358. https://doi.org/10.1016/j.chieco.2015.05.007

Dizaji, M., Mazdeh, M., \& Makui, A. (2018). Performance evaluation and ranking of direct sales stores using BSC approach and fuzzy multiple attribute decision-making methods. Decision Science Letters, 7(2), 197-210. https://doi.org/10.5267/j.dsl.2017.5.003

Dyson, R. G. (2000). Strategy, performance and operational research. Journal of the Operational Research Society, 51(1), 5-11. https://doi.org/10.1057/palgrave.jors.2600916

Farid, D., Nejati, M., \& Mirfakhredini, H. (2008). Balanced scorecard application in universities and higher education institutes: implementation guide in an Iranian context. Universitatii Bucuresti. Economic and Administrative, 2, 29-42.

Fijałkowska, J., \& Oliveira, C. (2018). Balanced scorecard in universities. Journal of Intercultural Management, 10(4), 57-83.

Gabus, A., \& Fontela, E. (1972). World problems, an invitation to further thought within the framework of DEMATEL. Battelle Geneva Research Center, Geneva, Switzerland.

Gamal, A., \& Soemantri, A. I. (2017). The effect of balanced scorecard on the private college performance (Case study at the University of WR Supratman Surabaya). Archives of Business Research, 5(5). https://doi.org/10.14738/abr.55.3093

Gitinavard, H., \& Akbarpour Shirazi, M. (2018). An extended intuitionistic fuzzy modified group complex proportional assessment approach. Journal of Industrial and Systems Engineering, 11(3), 229-246.

Gitinavard, H., \& Zarandi, M. H. F. (2016). A mixed expert evaluation system and dynamic intervalvalued hesitant fuzzy selection approach. International Journal of Mathematical, Computational, Physical, Electrical and Computer Engineering, 10, 337-345.

Ha, M.-H., \& Yang, Z. (2018). Modelling interdependency among attributes in MCDM: Its application in port performance measurement multi-criteria decision making in maritime studies and logistics (pp. 323-354). Springer. https://doi.org/10.1007/978-3-319-62338-2_12

Hassan, S. A. H. S., Tan, S. C., \& Yusof, K. M. (2016). MCDM for engineering education: Literature review and research issues engineering education for a smart society (pp. 204-214). Springer. https://doi.org/10.1007/978-3-319-60937-9_16

Hung, Y.-H., Chou, S.-C. T., \& Tzeng, G.-H. (2006). Using a fuzzy group decision approach-knowledge management adoption. Paper presented at the APRU DLI 2006 Conference.

Iranmanesh, S. H., Tavakoli, M., Heydari, K., Bastan, M., \& Yazdanparast, R. (2019). An integrated resilience engineering algorithm for performance optimisation of electricity distribution units. International Journal of Computer Applications in Technology, 60(3), 254-266.

https://doi.org/10.1504/IJCAT.2019.100303 
Kai, J. (2009). A critical analysis of accountability in higher education: Its relevance to evaluation of higher education. Chinese Education \& Society, 42(2), 39-51.

https://doi.org/10.2753/CED1061-1932420204

Kaplan, R. S., \& Norton, D. P. (1995). Putting the balanced scorecard to work. Performance Measurement, Management, and Appraisal Sourcebook, 66, 17511.

Kaplan, R. S., \& Norton, D. P. (2004). Strategy maps: Converting intangible assets into tangible outcomes. Harvard Business Press.

Karra, E. D., \& Papadopoulos, D. L. (2008). The evaluation of an academic institution using the balanced scorecard (academic scorecard): The case of University of Macedonia, Thessaloniki, Greece. Social Science Research Network (SSRN). https://doi.org/10.2139/ssrn.492783

Lin, C.-J., \& Wu, W.-W. (2008). A causal analytical method for group decision-making under fuzzy environment. Expert Systems with Applications, 34(1), 205-213. https://doi.org/10.1016/j.eswa.2006.08.012

Ling Sim, K., \& Chye Koh, H. (2001). Balanced scorecard: A rising trend in strategic performance measurement. Measuring Business Excellence, 5(2), 18-27. https://doi.org/10.1108/13683040110397248

Liou, T.-S., \& Wang, M.-J. J. (1992). Ranking fuzzy numbers with integral value. Fuzzy Sets and Systems, 50(3), 247-255. https://doi.org/10.1016/0165-0114(92)90223-Q

Martilla, J. A., \& James, J. C. (1977). Importance-performance analysis. The Journal of Marketing, 41(1), 77-79. https://doi.org/10.1177/002224297704100112

Mourato, J., Patrício, M. T., Loures, L., \& Morgado, H. (2019). Strategic priorities of Portuguese higher education institutions. Studies in Higher Education, 1-13. https://doi.org/10.1080/03075079.2019.1628202

Nazarko, J., \& Šaparauskas, J. (2014). Application of DEA method in efficiency evaluation of public higher education institutions. Technological and Economic Development of Economy, 20(1), 25-44. https://doi.org/10.3846/20294913.2014.837116

Nurcahyo, R., Wardhani, R. K., Habiburrahman, M., Kristiningrum, E., \& Herbanu, E. A. (2018). Strategic formulation of a higher education institution using balance scorecard. In 2018 4th International Conference on Science and Technology (ICST). IEEE. https://doi.org/10.1109/ICSTC.2018.8528294

Nuut, A. (2006). Evaluation of library performance: current developments in Estonia. Performance Measurement and Metrics, 7(3), 163-172. https://doi.org/10.1108/14678040610713129

Nuut, A., Lepik, A., \& Liivamägi, T. (2002). Developing performance measurement and quality - evaluation in Estonian research libraries: Survey of current situation. In Meaningful Measurement for Emerging Realities: Proceedings of 4th Northumbria International Conference on Performance Measurement in Libraries and Information Services (pp. 159-170). Association of Research Libraries.

Opricovic, S., \& Tzeng, G.-H. (2003). Defuzzification within a multicriteria decision model. International Journal of Uncertainty, Fuzziness and Knowledge-Based Systems, 11(05), 635-652. https://doi.org/10.1142/S0218488503002387

Özdemir, A., \& Tüysüz, F. (2017). An integrated fuzzy DEMATEL and fuzzy ANP based balanced scorecard approach: Application in Turkish Higher Education Institutions. Journal of Multiple-Valued Logic \& Soft Computing, 28(2), 251-287.

Papenhausen, C., \& Einstein, W. (2006). Implementing the Balanced Scorecard at a college of business. Measuring Business Excellence, 10(3), 15-22. https://doi.org/10.1108/13683040610685757

Rezaie, K., Dalfard, V. M., Hatami-Shirkouhi, L., \& Nazari-Shirkouhi, S. (2013). Efficiency appraisal and ranking of decision-making units using data envelopment analysis in fuzzy environment: A case study of Tehran stock exchange. Neural Computing and Applications, 23(1), 1-17.

https://doi.org/10.1007/s00521-012-1209-6

Ramasamy, N., Rajesh, R., Pugazhendhi, S., \& Ganesh, K. (2016). Development of a hybrid BSC-AHP model for institutions in higher education. International Journal of Enterprise Network Management, 7(1), 13-26. https://doi.org/10.1504/IJENM.2016.075174

Saaty, T. L. (1988). What is the analytic hierarchy process? Mathematical models for decision support (pp. 109-121). Springer. https://doi.org/10.1007/978-3-642-83555-1_5 
Saaty, T. L. (1996). Decision making with dependence and feedback: The analytic network process (Vol. 4922). RWS publications Pittsburgh.

Sarrico, C. S., Rosa, M. J., Teixeira, P. N., \& Cardoso, M. F. (2010). Assessing quality and evaluating performance in higher education: Worlds apart or complementary views? Minerva, 48(1), 35-54. https://doi.org/10.1007/s11024-010-9142-2

Slizyte, A., \& Bakanauskiene, I. (2007). Designing performance measurement system in organization. In Organizaciju vadyba: sisteminiai tyrimai (T. 43, pp. 135-148). Vytauto Didžiojo universiteto leidykla.

Sohrabvandi, S., Gitinavard, H., \& Ebrahimnezhad, S. (2017). A new extended analytical hierarchy process technique with incomplete interval-valued information for risk assessment in IT outsourcing. International Journal of Engineering, 30(5), 739-748.

Solgi, E., Husseini, S. M. M., Ahmadi, A., \& Gitinavard, H. (2019). A hybrid hierarchical soft computing approach for the technology selection problem in brick industry considering environmental competencies: A case study. Journal of Environmental Management, 248, 109219. https://doi.org/10.1016/j.jenvman.2019.06.120

Sun, C.-C. (2010). A performance evaluation model by integrating fuzzy AHP and fuzzy TOPSIS methods. Expert Systems with Applications, 37(12), 7745-7754. https://doi.org/10.1016/j.eswa.2010.04.066

Tesfamariam, S., \& Sadiq, R. (2006). Risk-based environmental decision-making using fuzzy analytic hierarchy process (F-AHP). Stochastic Environmental Research and Risk Assessment, 21(1), 35-50. https://doi.org/10.1007/s00477-006-0042-9

Tippins, M. J., \& Sohi, R. S. (2003). IT competency and firm performance: is organizational learning a missing link? Strategic Management Journal, 24(8), 745-761. https://doi.org/10.1002/smj.337

Tseng, M. L. (2010). Implementation and performance evaluation using the fuzzy network balanced scorecard. Computers \& Education, 55(1), 188-201. https://doi.org/10.1016/j.compedu.2010.01.004

Tzeng, G.-H., Chiang, C.-H., \& Li, C.-W. (2007). Evaluating intertwined effects in e-learning programs: A novel hybrid MCDM model based on factor analysis and DEMATEL. Expert Systems with Applications, 32(4), 1028-1044. https://doi.org/10.1016/j.eswa.2006.02.004

Vroon, R. (2010). How to effectively manage performance in a university. In 12th Twente Student Conference on IT. University of Twente. Twente, The Netherlands.

Wu, S.-I., \& Hung, J.-M. (2007). The performance measurement of cause-related marketing by balance scorecard. Total Quality Management \& Business Excellence, 18(7), 771-791. https://doi.org/10.1080/14783360701349831

Wu, W.-W., \& Lee, Y.-T. (2007). Developing global managers' competencies using the fuzzy DEMATEL method. Expert Systems with Applications, 32(2), 499-507. https://doi.org/10.1016/j.eswa.2005.12.005

Wu, H. Y., Lin, Y. K., \& Chang, C. H. (2011). Performance evaluation of extension education centers in universities based on the balanced scorecard. Evaluation and Program Planning, 34(1), 37-50. https://doi.org/10.1016/j.evalprogplan.2010.06.001

Yao, W., Xu, X., \& Chen, W. (2014) Towards evaluating the performance of higher education: From a non-financial perspective. In Z. Huang, C. Liu, J. He, \& G. Huang (Eds.), Web Information Systems Engineering - WISE 2013 Workshops. WISE 2013: Lecture Notes in Computer Science, Vol. 8182. (pp. 109-119). Springer, Berlin, Heidelberg. https://doi.org/10.1007/978-3-642-54370-8_10

Yüksel, İ., \& Dağdeviren, M. (2010). Using the fuzzy analytic network process (ANP) for Balanced Scorecard (BSC): A case study for a manufacturing firm. Expert Systems with Applications, 37(2), 1270-1278. https://doi.org/10.1016/j.eswa.2009.06.002

Zolfani, S. H., \& Ghadikolaei, A. S. (2013). Performance evaluation of private universities based on balanced scorecard: Empirical study based on Iran. Journal of Business Economics and Management, 14(4), 696-714. https://doi.org/10.3846/16111699.2012.665383 